\title{
Total Synthesis of Decahydroquinoline Poison Frog Alkaloids ent-cis-195A and cis-211A
}

\author{
Takuya Okada ${ }^{1, *,+}$, Naizhen $\mathrm{Wu}^{2,+}{ }^{+}$, Katsuki Takashima ${ }^{3}$, Jungoh Ishimura ${ }^{3}$, Hiroyuki Morita ${ }^{4}$, Takuya Ito ${ }^{4,5}$, \\ Takeshi Kodama ${ }^{4}$, Yuhei Yamasaki ${ }^{2}$, Shin-ichi Akanuma ${ }^{2}{ }^{\mathbb{D}}$, Yoshiyuki Kubo ${ }^{2}$, Ken-ichi Hosoya ${ }^{2}{ }^{\mathbb{D}}$, \\ Hiroshi Tsuneki ${ }^{2}$, Tsutomu Wada ${ }^{2}$, Toshiyasu Sasaoka ${ }^{2}$, Takahiro Shimizu ${ }^{2}$, Hideki Sakai ${ }^{2}$, Linda P. Dwoskin ${ }^{6}$, \\ Syed R. Hussaini ${ }^{7}$, Ralph A. Saporito ${ }^{8}$ and Naoki Toyooka ${ }^{1,3, *, \neq}$
}

check for updates

Citation: Okada, T.; Wu, N.; Takashima, K.; Ishimura, J.; Morita, H.; Ito, T.; Kodama, T.; Yamasaki, Y.; Akanuma, S.-i.; Kubo, Y.; et al. Total Synthesis of Decahydroquinoline Poison Frog Alkaloids ent-cis-195A and cis-211A. Molecules 2021, 26, 7529. https://doi.org/10.3390/ molecules26247529

Academic Editor: Francisco Leon

Received: 18 November 2021 Accepted: 10 December 2021 Published: 12 December 2021

Publisher's Note: MDPI stays neutral with regard to jurisdictional claims in published maps and institutional affiliations.

Copyright: (c) 2021 by the authors. Licensee MDPI, Basel, Switzerland. This article is an open access article distributed under the terms and conditions of the Creative Commons Attribution (CC BY) license (https:/ / creativecommons.org/licenses/by/ $4.0 /)$.
1 Graduate School of Innovative Life Science, University of Toyama, 3190 Gofuku, Toyama 930-8555, Japan

2 Graduate School of Medicine and Pharmaceutical Sciences, University of Toyama, 2630 Sugitani, Toyama 930-0194, Japan; wnz199242@gmail.com (N.W.); s1860342@ems.u-toyama.ac.jp (Y.Y.); akanumas@pha.u-toyama.ac.jp (S.-i.A.); kubo.yoshiyuki.jf@teikyou-u.ac.jp (Y.K.); hosoyak@pha.u-toyama.ac.jp (K.-i.H.); htsuneki@pha.u-toyama.ac.jp (H.T.); twada@pha.u-toyama.ac.jp (T.W.); tsasaoka@pha.u-toyama.ac.jp (T.S.); takshimi@pha.u-toyama.ac.jp (T.S.); sakaih@pha.u-toyama.ac.jp (H.S.)

3 Graduate School of Science and Engineering, University of Toyama, 3190 Gofuku, Toyama 930-8555, Japan; takashima@phar.kindai.ac.jp (K.T.); junirad@gmail.com (J.I.)

4 Institute of Natural Medicine, University of Toyama, 2630 Sugitani, Toyama 930-0194, Japan; hmorita@inm.u-toyama.ac.jp (H.M.); itoutaku@osaka-ohtani.ac.jp (T.I.); tkodama@inm.u-toyama.ac.jp (T.K.)

5 Faculty of Pharmacy, Osaka Ohtani University, Tondabayashi, Osaka 584-8540, Japan

6 Department of Pharmaceutical Sciences, College of Pharmacy, University of Kentucky, Lexington, KY 40536, USA; ldwoskin@email.uky.edu

7 Department of Chemistry and Biochemistry, The University of Tulsa, 800 S. Tucker Dr., Tulsa, OK 74104, USA; syed-hussaini@utulsa.edu

8 Department of Biology, John Carroll University, University Heights, OH 44118, USA; ralph.saporito@gmail.com

* Correspondence: tokada@eng.u-toyama.ac.jp (T.O.); toyooka@eng.u-toyama.ac.jp (N.T.); Tel.: +81-76-445-6859 (N.T.)

+ These authors equally contributed to this study.

$\ddagger$ Dedicated to my honorable Professor Daniel Comins for his outstanding contributions to heterocyclic and organometallic chemistry.

Abstract: The total synthesis of two decahydroquinoline poison frog alkaloids ent-cis-195A and cis-211A were achieved in 16 steps (38\% overall yield) and 19 steps (31\% overall yield), respectively, starting from known compound 1. Both alkaloids were synthesized from the common key intermediate $\mathbf{1 1}$ in a divergent fashion, and the absolute stereochemistry of natural cis-211A was determined to be $2 R, 4 a R, 5 R, 6 S$, and $8 \mathrm{a} S$. Interestingly, the absolute configuration of the parent decahydroquinoline nuclei of cis-211A was the mirror image of that of cis-195A, although both alkaloids were isolated from the same poison frog species, Oophaga (Dendrobates) pumilio, from Panama.

Keywords: decahydroquinoline; poison frog alkaloid; cis-195A; cis-211A

\section{Introduction}

The skin extracts of Neotropical poison frogs contain a variety of lipophilic alkaloids, and over 800 alkaloids have been isolated or detected to date [1]. Many of these alkaloids show remarkable biological activities on the nervous system such as nicotinic acetylcholine receptors [2,3]. Methods for chemical synthesis of poison frog alkaloids are needed to investigate the biological activities of poison frog alkaloids, as only minute amounts of natural alkaloids can be obtained from skin extracts [1]. Decahydroquinolines are a relatively large subgroup of poison frog alkaloids, and over 50 types have been detected. Among them, the alkaloid cis-195A is the parent member of this class that was originally isolated from a Panamanian population of Oophaga (Dendrobates) pumilio in 1969 [4]. The structure and 
absolute configuration of cis-195A were determined by X-ray crystallography, and several total syntheses have also been reported for this compound [5-22]. The alkaloid cis-211A was isolated from skin extracts of the same species of poison frog in 1987 [23]. However, no total synthesis of this alkaloid has been reported, and its absolute configuration remains unknown to date (Figure 1). As part of a program directed at studying the synthesis of poison frog alkaloids [24-38], herein, we report the total synthesis of ent-cis-195A and cis-211A. Both syntheses proceed via the common and key intermediate 11. The synthesis of cis-211A also enabled the determination of its absolute configuration.<smiles>CCC[C@H]1CC[C@H]2[C@@H](C)CCC[C@H]2N1</smiles>

cis-195A<smiles>CCC[C@H]1CC[C@@H]2[C@@H](CC[C@@H](O)[C@@H]2C)N1</smiles>

cis-211A

Figure 1. Structures of cis-195A and cis-211A.

\section{Results and Discussion}

Hydrogenation of known allyl derivative 1 [39] provided the ester 2, which was converted to enaminoester 4 via thiophenyl derivative 3 . The Michael-type conjugate addition reaction to 4 [25] gave adduct 5 as a single isomer in excellent yield. The ester moiety of 5 was elongated by the Arndt-Eistert reaction sequence to afford the homologated ester $\mathbf{6}$, which was transformed into the methyl ketone $\mathbf{8}$ via the corresponding Weinreb amide 7. Lemieux-Johnson oxidation of 8 provided the aldehyde $\mathbf{9}$, which was subjected to cyclization by treatment with DBU in refluxing benzene to yield the cis-fused enone 10c [25] without generating the trans-fused enone 10t. Selective formation of $10 \mathrm{c}$ was explained by the preferential formation of conformer $\mathbf{A}$ in the starting material 9 owing to the $A^{1,3}$ strain. Thus, epimerization at the 3-position of 9 occurred first, and then cyclization proceeded to provide the enone 10c as shown in Figure 2. With enone 10c in hand, the stage was set for the divergent synthesis of ent-cis-195A and cis-211A. The conjugate addition reaction to 10c with $\mathrm{Me}_{2} \mathrm{CuLi}$ followed by treatment of the resulting enolate with Comins' triflating agent [40] afforded the common and key intermediate $\mathbf{1 1}$ (Scheme 1).

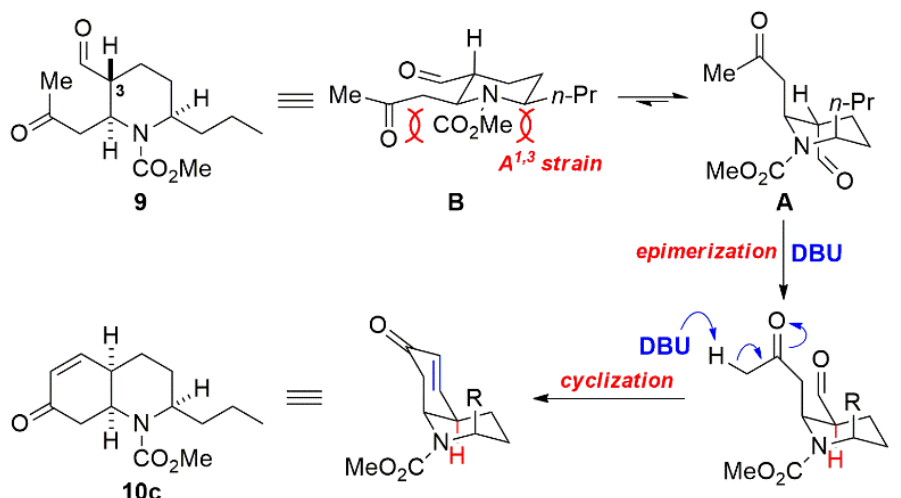

Figure 2. Reaction mechanism of the cyclization with epimerization of 9 . 

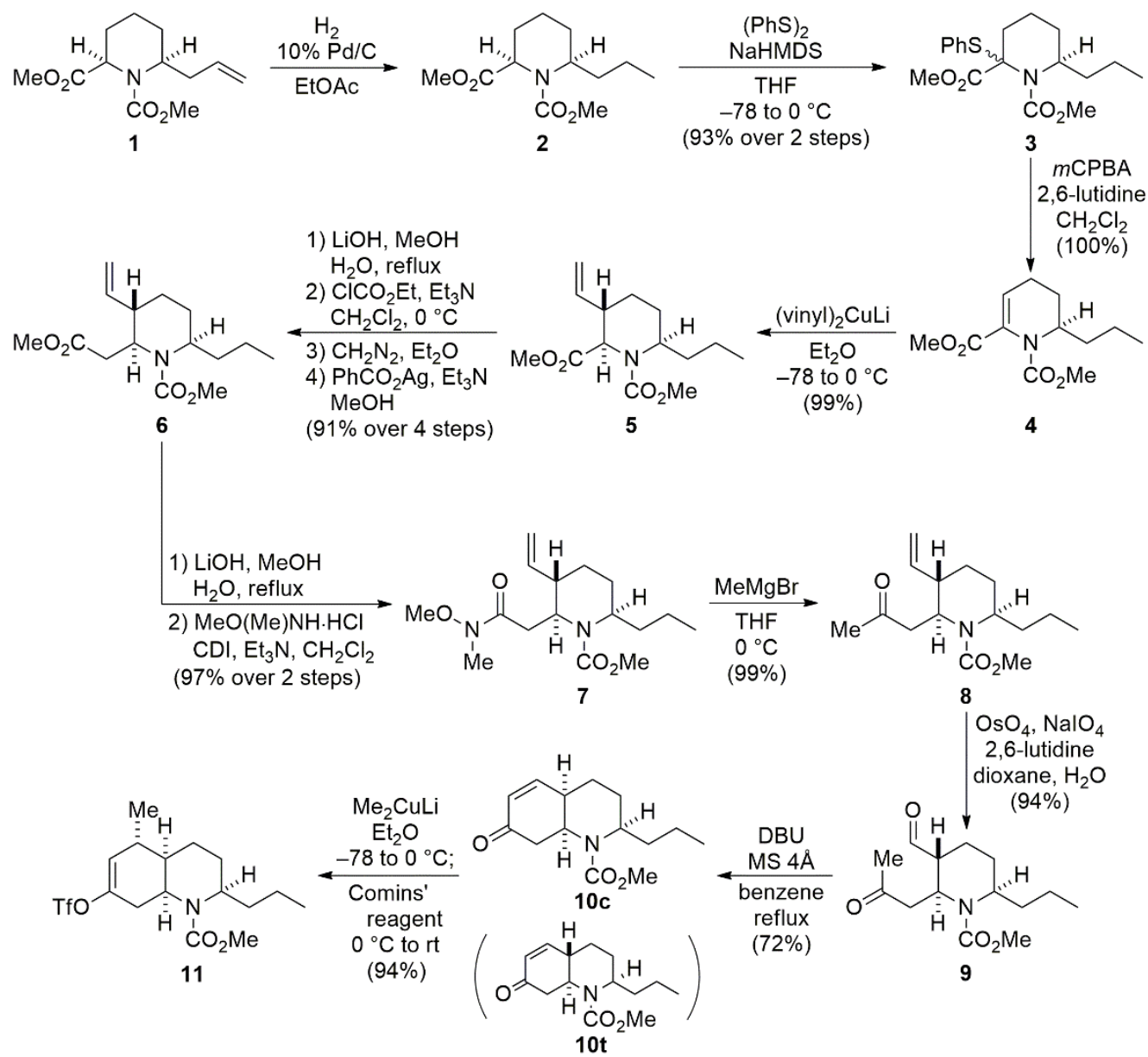

Scheme 1. Synthesis of the common and key intermediate enoltriflate $\mathbf{1 1 .}$

Finally, global hydrogenation of $\mathbf{1 1}$ and deprotection of the methyl carbamate moiety in 12 using TMSI in $\mathrm{CHCl}_{3}$ at $50{ }^{\circ} \mathrm{C}$ provided ent-cis-195A, as shown in Scheme 2. The ${ }^{1} \mathrm{H}$ and ${ }^{13} \mathrm{C}$-NMR spectra of synthetic ent-cis-195A were in good agreement with those reported in the literature [22].

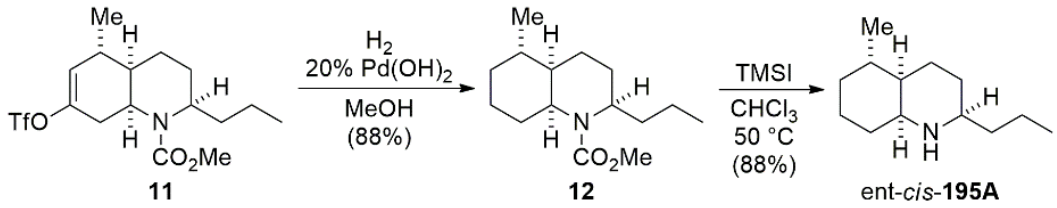

Scheme 2. Total synthesis of ent-cis-195A.

The enol triflate 11 was converted to olefin 13 by palladium-catalyzed reduction. Epoxidation of 13 by $m$ CPBA proceeded smoothly to give the epoxide 14, unfortunately, as a 1:1 mixture of epoxide 14. Hydroboration of $\mathbf{1 3}$ using $\mathrm{BH}_{3}-\mathrm{SMe}_{2}$ in toluene provided the alcohol $\mathbf{1 5}$ and the mixture of alcohols $\mathbf{1 6}$ and $\mathbf{1 7}$. The structure of $\mathbf{1 5}$ was determined by NOESY. The NOESY experiments of $\mathbf{1 5}$ revealed a syn relationship between the methyl group at C-5 and H-6 based on the NOESY correlations from $\mathrm{H}_{3}-5$ to H-6. However, the separation of $\mathbf{1 6}$ and $\mathbf{1 7}$ was difficult at this stage. For completion of the synthesis of cis211A, inversion of the hydroxyl group in 15 was necessary. For this purpose, we subjected 15 to the Mitsunobu reaction; however, all attempts failed and resulted in the recovery of 15. Next, we examined hydroxyl inversion of $\mathbf{1 5}$ via ketone 19. Any oxidations of $\mathbf{1 5}$ using Swern, a $\mathrm{SO}_{3}$-pyridine complex, PCC, PDC, DMP, or TPAP were not successful, and the starting material was recovered. Only oxidation using AZADOL ${ }^{\circledR}[41]$ proceeded smoothly 
to yield the desired ketone 19 in good yield. In addition, the AZADOL ${ }^{\circledR}$ oxidation of the mixture of $\mathbf{1 6}$ and $\mathbf{1 7}$ afforded the ketones $\mathbf{1 9}$ and $\mathbf{2 0}$ in $34 \%$ and $66 \%$ yield, respectively, which could be easily separated by column chromatography. Thus, we succeeded to obtain the ketone 19 from 13 in 64\% (49\% + 15\%) overall yield, as shown in Scheme 3. The conformation of ketone 19 is depicted in 19-A. The reduction of 19 from the concave face was needed to obtain the desired alcohol 16. We expected that the reduction of 19 would proceed from the concave face, as shown in 19-A, because of the steric hindrance of the $\alpha$-axial methyl group. However, the use of a small reducing agent like $\mathrm{NaBH}_{4}$ or $\mathrm{LiAlH}_{4}$ reduced $\mathbf{1 9}$ from the convex face to afford $\mathbf{1 5}$ as the sole product. To secure the reduction from the concave face, we tried the large reducing agent L-Selectride ${ }^{\circledR}$; however, the reduction did not proceed, and only ketone 19 was recovered. Fortunately, SuperHydride ${ }^{\circledR}$, a moderately sized reducing agent, was the best match for this substrate, and the reduction proceeded from the concave face to provide the desired alcohol $\mathbf{1 6}$ as the major product (16:15 = 9:1). The final deprotection of the urethane moiety in 16 was also troublesome. First, we applied the same reaction conditions used for ent-cis-195A (TMSI in refluxing $\mathrm{CHCl}_{3}$ ) to cleave the methyl carbamate; however, the reaction did not proceed. Then, other reaction conditions, such as the use of $n$-PrSLi/HMPA or $\mathrm{KOH} / i-\mathrm{PrOH}$ in a sealed tube at $130^{\circ} \mathrm{C}$, resulted in the recovery of the starting material. Finally, we used TMSI in refluxing MeCN, and the reaction proceeded cleanly to yield cis-211A, as shown in Scheme 3.<smiles>CCC[C@H]1CC[C@H]2[C@H](O)C=C(O)C[C@@H]2N1C(C)=O</smiles>
11

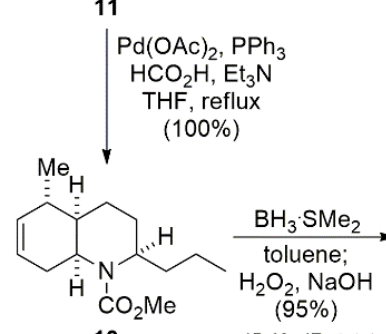
13 $\mathrm{mCPBA}$ $\mathrm{CH}_{2} \mathrm{Cl}_{2}$<smiles>CCC[C@H]1CC[C@H]2[C@H](CC3OC3[C@@H]2C)N1C(C)=O</smiles>
14

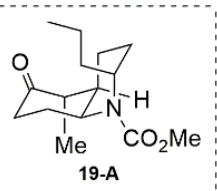<smiles>[R6]C1CC[C@@H]2[C@@H](CC[C@H](CCC)N2C(C)=O)[C@H]1C</smiles>

18

4 $\mathrm{R}-\mathrm{CO}_{2} \mathrm{H}$ $\left(\mathrm{R}=p-\mathrm{NO}_{2} \mathrm{C}_{6} \mathrm{H}_{4}\right)$ DEAD, PPh

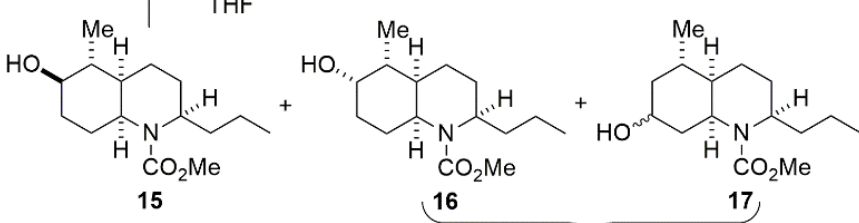
AZADOL ${ }^{\otimes}$ $\mathrm{NaOCl} \cdot 5 \mathrm{H}_{2} \mathrm{O}$ $\mathrm{CH}_{2} \mathrm{Cl}_{2}$ $\mathrm{NaHCO}_{3}$ aq<smiles>CCCC[C@H]1CC[C@@H]2C([N+](=O)[O-])C(=O)CC[C@@H]2N1C(C)=O</smiles>

19 (49\% over 2 steps from 13$)$ Super- $\mathrm{H}^{\circledast}$ THF $0^{\circ} \mathrm{C}$
$(100 \%)$ 16:15=9:1

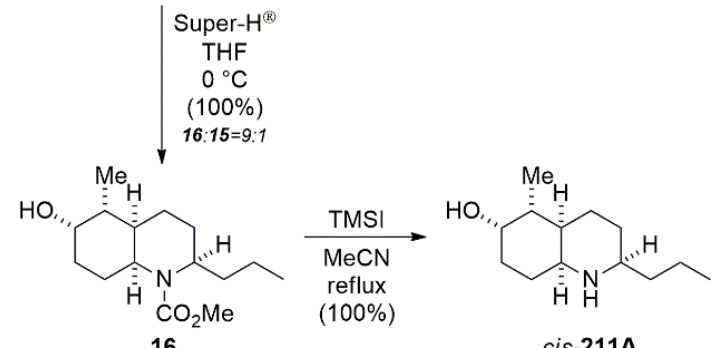

16
AZADOL ${ }^{\circledR}$

$\mathrm{NaOCl} \cdot 5 \mathrm{H}_{2} \mathrm{O}$ $\mathrm{CH}_{2} \mathrm{Cl}_{2} \quad$ 19:20=1:2 $\mathrm{NaHCO}_{3}$ aq. $(100 \%)$

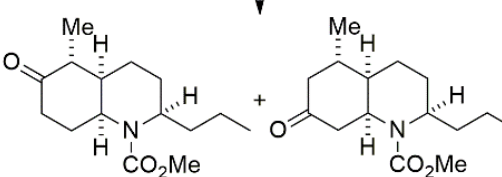

19 (15\% over 2 steps from 13$)$ 20

Scheme 3. Total synthesis of cis-211A. 
The ${ }^{1} \mathrm{H}$ - and ${ }^{13} \mathrm{C}-\mathrm{NMR}$ spectra of synthetic cis-211A were in good agreement with the reported values [23]. The absolute stereochemistry of natural cis-211A was determined unambiguously by the present synthesis to be $2 R, 4 \mathrm{a} R, 5 R, 6 \mathrm{~S}$, and $8 \mathrm{a} S$ by comparison of the optical rotation of synthetic cis-211A $\left([\alpha]_{\mathrm{D}}^{25}-11.5\left(c 0.2, \mathrm{CHCl}_{3}\right)\right)$ with the reported value $\left([\alpha]_{\mathrm{D}}-11.7\left(c 1.0, \mathrm{CHCl}_{3}\right)\right)$ [23]. Interestingly, cis-195A and cis-211A were both isolated from the same poison frog, Oophaga (Dendrobates) pumilio (Dendrobatidae) from Panama; however, the absolute stereochemistry of the parent decahydroquinoline nuclei of cis-195A is opposite to that of cis-211A. The NMR spectra $\left({ }^{1} \mathrm{H}-\mathrm{NMR},{ }^{13} \mathrm{C}-\mathrm{NMR}\right)$ of all synthesized compounds are listed in Supplementary Materials.

To further investigate the effect of the stereochemistry of the hydroxyl group at the 6-position on the inhibitory activity against nicotinic acetylcholine $(\mathrm{ACh})$ receptors, we also synthesized 6-epi-211A by deprotection of the methoxycarbonyl group in 15, as shown in Scheme 4.

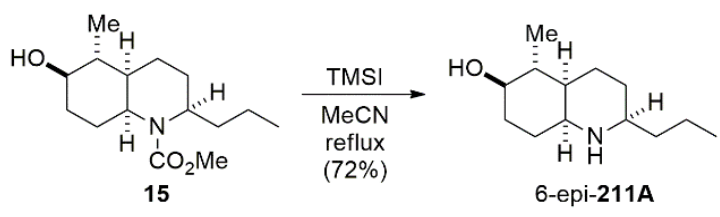

Scheme 4. Synthesis of 6-epi-211A.

Nicotinic ACh receptors are ligand-gated cation channels [42,43]. Homomeric $\alpha 7-$ and heteromeric $\alpha 4 \beta 2$-pentamers are the major subtypes of nicotinic receptors found in the central nervous system [44]. It has been reported that (-)-cis-195A, a natural cisdecahydroquinoline alkaloid (formerly referred to as Pumiliotoxin C), blocks ganglionic nicotinic ACh receptors in pheochromocytoma PC12 cells [45] and that the synthetic analog (+)-cis-195A is more potent than (-)-cis-195A at inhibiting nicotinic receptor activity [3]. Here, we examined the effects of ent-cis-195A, cis-211A, and 6-epi-211A on $\alpha 7$ - and $\alpha 4 \beta 2$ nicotinic ACh receptors ectopically expressed in Xenopus oocytes. If the criterion for partial inhibition by an alkaloid is defined as a $\geq 20 \%$ decrease in the peak amplitude of AChelicited currents, then ent-cis-195A $(1-10 \mu \mathrm{M})$ showed no apparent inhibitory effects on $\alpha 7-$ and $\alpha 4 \beta 2$-receptor-mediated currents (Figure 3A,B). cis-211A and 6-epi-211A at 10 $\mu \mathrm{M}$ partially inhibited $\alpha 7$-receptor-mediated currents by $38 \%$ and $31 \%$, respectively, while both alkaloids at $10 \mu \mathrm{M}$ showed negligible effects on $\alpha 4 \beta 2$-receptor-mediated currents (Figure 3C-F). Analysis of their structure-activity relationship suggested that the 6-hydroxy moiety of cis-211A and 6-epi-211A might contribute to the partial blockade of $\alpha 7$-nicotinic $\mathrm{ACh}$ receptors. The ligand-binding assays showed that none of these alkaloids affected $\left[{ }^{3} \mathrm{H}\right]$ nicotine and $\left[{ }^{3} \mathrm{H}\right]$ methyllycaconitine binding to rat whole brain membranes (data not shown). Therefore, cis-211A and 6-epi-211A were believed to act as noncompetitive blockers of $\alpha 7$-nicotinic receptors, although they were less potent and not as highly selective.

Neuronal nicotinic ACh receptors play a role in cerebral and retinal physiology. The blood-brain barrier (BBB) and inner blood-retinal barrier (BRB) directly segregate the brain and retina, respectively, from the circulating blood. It has been reported that putative nicotine- and verapamil-sensitive cationic drug transport systems at the BBB and inner $B R B$, respectively, are involved in the facilitative distribution of their substrates to the central nervous system [46,47]. To evaluate the recognition of ent-cis-195A and cis-211A as substrates for these cationic drug transport systems, we performed an inhibition study using conditionally immortalized rat BBB and inner BRB model cells, known as TR-BBB13 and TR-iBRB2 cells [48,49]. As shown in Table 1, ent-cis-195A exhibited an inhibitory effect on $\left[{ }^{3} \mathrm{H}\right]$ nicotine transport into TR-BBB13 cells and $\left[{ }^{3} \mathrm{H}\right]$ verapamil transport into TR-iBRB2 cells by more than $40 \%$. In addition, the presence of cis-211A significantly attenuated $\left[{ }^{3} \mathrm{H}\right]$ nicotine and $\left[{ }^{3} \mathrm{H}\right]$ verapamil uptake by TR-BBB13 and TR-iBRB2 cells, respectively, by at least $29 \%$. These results suggest that ent-cis-195A and cis-211A are recognized by the cationic drug transport systems at the BBB and inner BRB. It is possible that these 
derivatives reach the brain and retina via the cationic drug transport systems and show neuronal effects in the CNS.
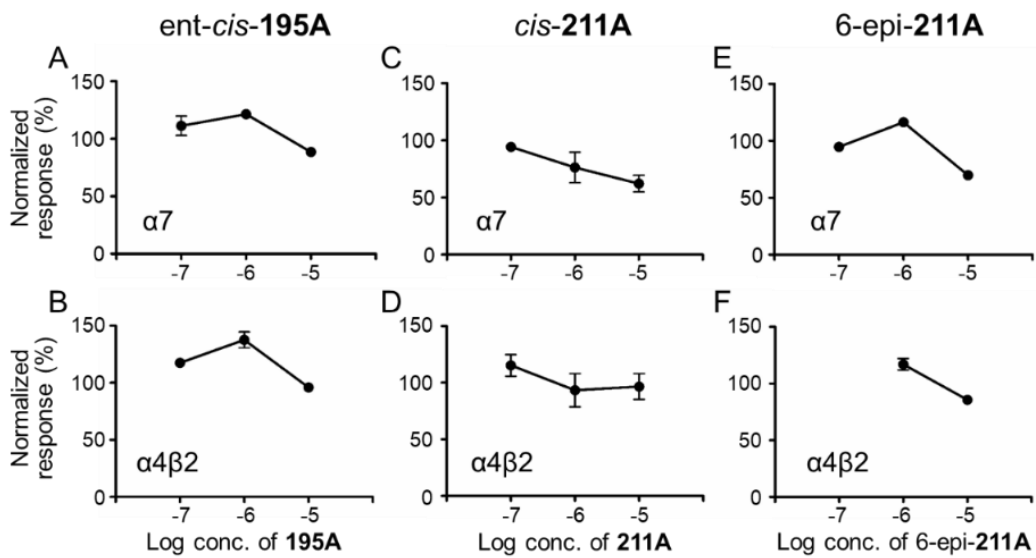

Figure 3. The effects of ent-cis-195A, cis-211A, and 6-epi-211A on $\alpha 7$ - and $\alpha 4 \beta 2$-nicotinic acetylcholine receptors expressed in Xenopus oocytes. (A-F). Concentration-inhibition curves for ent-cis-195A $(\mathbf{A}, \mathbf{B})$, cis-211A (C,D), and 6-epi-211A (E,F) on $\alpha 7-(\mathbf{A}, \mathbf{C}, \mathbf{E})$ and $\alpha 4 \beta 2$-nicotinic receptors (B,D,F). Current response to acetylcholine (ACh) in the presence of alkaloid was normalized to the current elicited by ACh alone in the same oocyte and averaged. Values represent the mean \pm S.E.M. (A-D): $n=3-5$, E: $n=3-4, \mathrm{~F}: n=4-5$.

Table 1. Inhibitory effects of ent-cis-195A and cis-211A on $\left[{ }^{3} \mathrm{H}\right]$ nicotine uptake by TR-BBB13 cells and $\left[{ }^{3} \mathrm{H}\right]$ verapamil uptake by TR-iBRB2 cells.

\begin{tabular}{ccc}
\hline Conditions & Percentage of Control & \\
\hline & {$\left[{ }^{3} \mathbf{H}\right]$ Nicotine Uptake } & {$\left[{ }^{3} \mathbf{H}\right]$ Verapamil Uptake } \\
Control & $100 \pm 5$ & $100 \pm 4$ \\
ent-cis-195A & $31.6 \pm 1.7^{*}$ & $66.9 \pm 2.5^{*}$ \\
cis-211A & $60.0 \pm 3.5^{*}$ & $70.6 \pm 4.1^{*}$ \\
\hline
\end{tabular}

[ $\left.{ }^{3} \mathrm{H}\right]$ Nicotine uptake $(0.1 \mu \mathrm{Ci}$ /well, $6.0 \mathrm{nM})$ by TR-BBB13 cells was measured at $37^{\circ} \mathrm{C}$ for $10 \mathrm{sec}$ in the absence (control) or presence of test compounds at $200 \mu \mathrm{M}$ with $1.0 \%$ dimethyl sulfoxide (DMSO). Similarly, $\left[{ }^{3} \mathrm{H}\right]$ verapamil uptake by TR-iBRB2 cells was performed at $37^{\circ} \mathrm{C}$ for $3 \mathrm{~min}$. Each value represents the mean \pm standard error of the mean S.E.M. $(n=3-6){ }^{*} p<0.01$, significantly different from the control in Dunnett's test.

In summary, we achieved the total syntheses of ent-cis-195A and cis-211A in a divergent process from the key and common intermediate 11. The absolute stereochemistry of natural cis-211A was determined to be $2 R, 4 \mathrm{a} R, 5 R, 6 S$, and $8 \mathrm{a} S$ by comparison with the data obtained from our total synthesis. The inhibitory effects of ent-cis-195A, cis-211A, and 6-epi-211A on nicotinic ACh receptors were also investigated. The results showed that cis-211A and 6-epi-211A had better inhibitory effects on the $\alpha 7$-receptor than that of ent-cis-195A, and none of the compounds showed inhibitory effects on the $\alpha 4 \beta 2$-receptor at the same concentration. These results suggested that cis-211A and 6-epi-211A could be applied as important tools for studying the brain and nervous system. More interestingly, the absolute configuration of the decahydroquinoline nuclei of cis-211A was a mirror image of that of cis-195A, even though both alkaloids were isolated from Oophaga (Dendrobates) pumilio from Panama.

\section{Materials and Methods}

\subsection{Chemistry}

\subsubsection{General Information}

Chemicals were purchased from Sigma-Aldrich, Merck (Darmstadt, Germany), FUJIFILM Wako Chemicals (Osaka, JAPAN), Nacalai Tesque, Tokyo Chemical Industry (Tokyo, Japan), and Kanto Chemical (Tokyo, Japan) and used without further purification. Col- 
umn chromatography was done on Cica silica gel 60N (spherical, neutral; particle size, 63-210 nm, Kanto Chemical), while thin-layer chromatography was performed using Merck silica gel $60 \mathrm{~F}_{254}$ plates. Melting points were taken on a Yanaco micromelting point apparatus and are uncorrected. The nuclear magnetic resonance (NMR) spectra were acquired in the specified solvent in JEOL JNM-A400 (400 and $100 \mathrm{MHz}$ for ${ }^{1} \mathrm{H}$ and ${ }^{13} \mathrm{C}$, respectively) or JEOL JNM-ECX500 (500 and $125 \mathrm{MHz}$ for ${ }^{1} \mathrm{H}$ and ${ }^{13} \mathrm{C}$, respectively). The chemical shifts $(\delta)$ are reported in ppm downfield from TMS, and coupling constants $(J)$ are expressed in Hertz. IR spectra were measured with a JASCO FT/IR-460 Plus spectrophotometer (JASCO Corp., Tokyo, Japan). The low-resolution and high-resolution mass spectra were obtained with a Shimadzu GCMS-QP 500 mass spectrometer (Shimadzu Corp., Kyoto, Japan), JEOL D-200, or JEOL AX505 mass spectrometer (JEOL Ltd., Tokyo, Japan) in the electron impact mode at the ionization potential of $70 \mathrm{eV}$.

3.1.2. Synthesis of (6R)-2-Phenylsulfanyl-6-propyl-piperidine-1,2-dicarboxylic Acid Dimethyl Ester (3)

To a stirred solution of 1 [39] (2.51 g, $10.39 \mathrm{mmol})$ in EtOAc (30 mL) was added 10\% $\mathrm{Pd} / \mathrm{C}(30 \mathrm{mg})$, and the resulting mixture was hydrogenated at $1 \mathrm{~atm}$ for $16 \mathrm{~h}$. The catalyst was removed through a celite pad and washed with EtOAc $(5 \mathrm{~mL} \times 3)$. The filtrate and washings were combined and evaporated to give 2 , which was essentially pure and used directly in the next step. To a stirred solution of 2 in THF $(30 \mathrm{~mL})$ was added a solution of sodium bis(trimethylsilyl)amide $(1.9 \mathrm{M}$ in THF, $8.20 \mathrm{~mL}, 15.59 \mathrm{mmol})$ at $-78{ }^{\circ} \mathrm{C}$, and the reaction mixture was stirred at $-78{ }^{\circ} \mathrm{C}$ for $30 \mathrm{~min}$. To the reaction mixture was added a solution of diphenyl disulfide $(3.40 \mathrm{~g}, 15.59 \mathrm{mmol})$ in THF $(15 \mathrm{~mL})$, and the resulting mixture was stirred at $0{ }^{\circ} \mathrm{C}$ for $30 \mathrm{~min}$. The solvent was evaporated, and the residue was chromatographed on $\mathrm{SiO}_{2}(50 \mathrm{~g}$, acetone $/ n$-hexane $=1 / 30)$ to give $3(3.39 \mathrm{~g}, 9.66 \mathrm{mmol}$, $93 \%$ in 2 steps) as a yellow oil as a mixture of diastereomers.

${ }^{1} \mathrm{H}-\mathrm{NMR}\left(400 \mathrm{MHz} \mathrm{CDCl}_{3}\right) \delta: 0.90$ and $0.94(3 \mathrm{H}$, each $\mathrm{t}, J=7.2 \mathrm{~Hz}), 1.28-1.79(8 \mathrm{H}, \mathrm{m})$, 1.90-1.98 $(1 \mathrm{H}, \mathrm{m}), 2.26-2.38(1 \mathrm{H}, \mathrm{m}), 3.49$ and $3.62(3 \mathrm{H}$, each $\mathrm{s}), 3.73$ and $3.74(3 \mathrm{H}$, each s), 4.06-4.20 (1H, m), 7.29-7.35 (3H, m), 7.73-7.78 (2H, m).

3.1.3. Synthesis of (6R)-6-Propyl-5,6-dihydro-4H-pyridine-1,2-dicarboxylic Acid Dimethyl Ester (4)

To a stirred solution of $3(1.27 \mathrm{~g}, 3.61 \mathrm{mmol})$ in $\mathrm{CH}_{2} \mathrm{Cl}_{2}(12 \mathrm{~mL})$ was added 2,6-lutidine $(0.84 \mathrm{~mL}, 9.03 \mathrm{mmol})$, and then $\mathrm{mCPBA}(70 \%, 1.50 \mathrm{~g}, 8.67 \mathrm{mmol})$ was added to the reaction mixture in four portions in $15 \mathrm{~min}$ intervals at $0{ }^{\circ} \mathrm{C}$. The resulting mixture was stirred at room temperature for $8 \mathrm{~h}$. The reaction was quenched with $10 \% \mathrm{Na}_{2} \mathrm{~S}_{2} \mathrm{O}_{3}$ in sat. $\mathrm{NaHCO}_{3}$ (aq.) $(25 \mathrm{~mL})$, and the aqueous mixture was diluted with EtOAc. The layers were separated, and the aqueous layer was extracted with EtOAc $(5 \mathrm{~mL} \times 3)$. The organic layer and extracts were combined and washed with brine, $10 \% \mathrm{HCl}$ (aq.), and brine, successively. The organic layer was dried and evaporated to give a pale yellow oil, which was chromatographed on $\mathrm{SiO}_{2}(20 \mathrm{~g}$, acetone $/ n$-hexane $=1 / 30)$ to give $4(871 \mathrm{mg}, 3.61 \mathrm{mmol}, 100 \%)$ as pale yellow oil.

${ }^{1} \mathrm{H}-\mathrm{NMR}\left(400 \mathrm{MHz} \mathrm{CDCl}_{3}\right) \delta: 0.93(3 \mathrm{H}, \mathrm{t}, J=7.3 \mathrm{~Hz}), 1.17-1.28(1 \mathrm{H}, \mathrm{m}), 1.37-1.58(3 \mathrm{H}$, $\mathrm{m}), 1.69-1.76(1 \mathrm{H}, \mathrm{m}), 1.79-1.89(1 \mathrm{H}, \mathrm{m}), 2.15-2.22(2 \mathrm{H}, \mathrm{m}), 3.70(3 \mathrm{H}, \mathrm{s}), 3.76(3 \mathrm{H}, \mathrm{s}), 4.42$ $(1 \mathrm{H}, \mathrm{br}), 6.06(1 \mathrm{H}, \mathrm{t}, J=3.6 \mathrm{~Hz}) ;{ }^{13} \mathrm{C}-\mathrm{NMR}\left(125 \mathrm{MHz} \mathrm{CDCl}_{3}\right) \delta: 13.75,19.10,19.53,25.70$, 31.62, 50.99, 51.87, 52.85, 122.08, 129.87, 154.63, 165.56; IR (neat): 1231, 1275, 1330, 1442, 1714, $1733 \mathrm{~cm}^{-1}$; MS (EI): $m / z 241\left(\mathrm{M}^{+}\right)$; HRMS (EI) Calcd for $\mathrm{C}_{12} \mathrm{H}_{19} \mathrm{NO}_{4} 241.1314\left(\mathrm{M}^{+}\right)$; Found $241.1315 ;[\alpha]_{\mathrm{D}}{ }^{19}-68.0\left(c 1.00, \mathrm{CHCl}_{3}\right)$.

3.1.4. Synthesis of $(2 R, 3 S, 6 R)$-6-Propyl-3-vinyl-piperidine-1,2-dicarboxylic Acid Dimethyl ester (5)

To a stirred solution of $\mathrm{CuI}(1.31 \mathrm{~g}, 6.90 \mathrm{mmol})$ in $\mathrm{Et}_{2} \mathrm{O}(15 \mathrm{~mL})$ was added a solution of vinyl lithium, prepared from tetravinyltin $(0.61 \mathrm{~mL}, 3.45 \mathrm{mmol})$ and $\mathrm{MeLi}(1.13 \mathrm{M}$ in $\left.\mathrm{Et}_{2} \mathrm{O}, 12.20 \mathrm{~mL}, 13.80 \mathrm{mmol}\right)$ in $\mathrm{Et}_{2} \mathrm{O}(15 \mathrm{~mL})$ at $0{ }^{\circ} \mathrm{C}$ for $30 \mathrm{~min}$, at $-78^{\circ} \mathrm{C}$, and the reaction mixture was warmed to $-35^{\circ} \mathrm{C}$ for $30 \mathrm{~min}$. The reaction mixture was recooled to $-78{ }^{\circ} \mathrm{C}$, 
and a solution of $4(555 \mathrm{mg}, 2.30 \mathrm{mmol})$ in $\mathrm{Et}_{2} \mathrm{O}(7 \mathrm{~mL})$ was added to the reaction mixture. The resulting mixture was gradually warmed to $0^{\circ} \mathrm{C}$ and stirred at the same temperature for $1 \mathrm{~h}$. The reaction was quenched with sat. $\mathrm{NH}_{4} \mathrm{Cl}$ (aq.) $(30 \mathrm{~mL})$. The aqueous mixture was diluted with $\mathrm{CH}_{2} \mathrm{Cl}_{2}(30 \mathrm{~mL})$, and the resulting mixture was filtered. The filtrate was separated, and the aqueous layer was extracted with $\mathrm{CH}_{2} \mathrm{Cl}_{2}(10 \mathrm{~mL} \times 3)$. The organic layer and extracts were combined, dried, and evaporated to give a colorless oil, which was chromatographed on $\mathrm{SiO}_{2}(20 \mathrm{~g}$, acetone $/ n$-hexane $=1 / 30)$ to give 5 (613 mg, $2.28 \mathrm{mmol}$, $99 \%$ ) as a colorless oil.

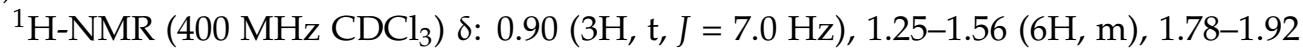
$(2 \mathrm{H}, \mathrm{m}), 3.08(1 \mathrm{H}, \mathrm{br}), 3.71(3 \mathrm{H}, \mathrm{s}), 3.74(3 \mathrm{H}, \mathrm{s}), 4.17-4.18(1 \mathrm{H}, \mathrm{m}), 4.88(1 \mathrm{H}, \mathrm{br}), 5.09-5.15$ $(2 \mathrm{H}, \mathrm{m}), 5.81(1 \mathrm{H}, \mathrm{ddd}, J=17.1,10.7,6.4 \mathrm{~Hz}) ;{ }^{13} \mathrm{C}-\mathrm{NMR}\left(125 \mathrm{MHz} \mathrm{CDCl}_{3}\right) \delta: 13.86,19.88$, 21.03, 22.45, 34.59, 36.52, 50.96, 51.99, 52.75, 55.07, 115.16, 139.00, 157.08, 172.86; IR (neat): 1200, 1340, 1363, 1448, 1506, 1558, 1683, 1699, $1734 \mathrm{~cm}^{-1}$; MS (EI): $m / z 269\left(\mathrm{M}^{+}\right)$; HRMS (EI) Calcd for $\mathrm{C}_{14} \mathrm{H}_{23} \mathrm{NO}_{4} 269.1627\left(\mathrm{M}^{+}\right)$; Found 269.1631; $[\alpha]_{\mathrm{D}}{ }^{25}+53.6\left(c 1.00, \mathrm{CHCl}_{3}\right)$.

3.1.5. Synthesis of (2S, 3S, 6R)-2-Methoxycarbonylmethyl-6-propyl-3-vinyl-piperidine-1 -carboxylic Acid Methyl Ester (6)

To a stirred solution of $5(428 \mathrm{mg}, 1.59 \mathrm{mmol})$ in $\mathrm{MeOH}(6 \mathrm{~mL})$ and $\mathrm{H}_{2} \mathrm{O}(2 \mathrm{~mL})$ was added $\mathrm{LiOH} \cdot \mathrm{H}_{2} \mathrm{O}(266 \mathrm{mg}, 6.36 \mathrm{mmol})$, and the resulting mixture was refluxed for $2 \mathrm{~h}$. After cooling, $\mathrm{MeOH}$ was evaporated, and the residue was acidified with $10 \% \mathrm{HCl}$ (aq.) $(5 \mathrm{~mL})$. The aqueous mixture was extracted with EtOAc $(3 \mathrm{~mL} \times 5)$. The organic extracts were combined, dried, and evaporated to give a yellow oil, which was used directly in the next step. To a stirred solution of the above oil in THF $(10 \mathrm{~mL})$ were added $\mathrm{ClCO}_{2} \mathrm{Et}$ $(0.18 \mathrm{~mL}, 1.91 \mathrm{mmol})$ and $\mathrm{Et}_{3} \mathrm{~N}(0.27 \mathrm{~mL}, 1.91 \mathrm{mmol})$ at $0{ }^{\circ} \mathrm{C}$, and the resulting mixture was stirred at $0{ }^{\circ} \mathrm{C}$ for $1 \mathrm{~h}$. The reaction mixture was diluted with $\mathrm{Et}_{2} \mathrm{O}(3 \mathrm{~mL})$, and $\mathrm{Et}_{3} \mathrm{~N} \cdot \mathrm{HCl}$ was filtered off. The filtrate was evaporated to give a yellow oil, which was used directly in the next step. To a stirred solution of the above oil in $\mathrm{Et}_{2} \mathrm{O}(10 \mathrm{~mL})$ was added a solution of $\mathrm{CH}_{2} \mathrm{~N}_{2}$ in $\mathrm{Et}_{2} \mathrm{O}$ at $0{ }^{\circ} \mathrm{C}$, and the reaction mixture was stirred at room temperature for $16 \mathrm{~h}$. The solvent was evaporated to give a yellow oil, which was dissolved in $\mathrm{MeOH}(10 \mathrm{~mL})$. To the $\mathrm{MeOH}$ solution were added $\mathrm{AgCO}_{2} \mathrm{Ph}(37 \mathrm{mg}, 0.16 \mathrm{mmol})$ and $\mathrm{Et}_{3} \mathrm{~N}(0.45 \mathrm{~mL}$, $3.18 \mathrm{mmol}$ ), and the resulting mixture was stirred at room temperature for $24 \mathrm{~h}$. The reaction mixture was diluted with $\mathrm{Et}_{2} \mathrm{O}$, and the insoluble material was filtered off. The filtrate was evaporated to give a black oil, which was chromatographed on $\mathrm{SiO}_{2}(20 \mathrm{~g}$, EtOAc $/ n$-hexane $=1 / 30)$ to give $6(409 \mathrm{mg}, 1.45 \mathrm{mmol}, 91 \%$ in 4 steps $)$ as a colorless oil.

${ }^{1} \mathrm{H}-\mathrm{NMR}\left(400 \mathrm{MHz} \mathrm{CDCl}_{3}\right) \delta: 0.92(3 \mathrm{H}, \mathrm{t}, J=7.3 \mathrm{~Hz}), 1.20-1.42(4 \mathrm{H}, \mathrm{m}), 1.43-1.52$ (2H, m), 1.78-1.92 (2H, m), $2.32(1 \mathrm{H}, \mathrm{br}), 2.54(1 \mathrm{H}, \mathrm{dd}, J=14.9,4.8 \mathrm{~Hz}), 2.65(1 \mathrm{H}, \mathrm{dd}$, $J=14.9,10.1 \mathrm{~Hz}), 3.66(3 \mathrm{H}, \mathrm{s}), 3.68(3 \mathrm{H}, \mathrm{s}), 4.12(1 \mathrm{H}, \mathrm{br}), 4.61(1 \mathrm{H}, \mathrm{br}), 5.06(1 \mathrm{H}, \mathrm{dt}, J=10.6$, $1.4 \mathrm{~Hz}), 5.09(1 \mathrm{H}, \mathrm{dt}, J=17.2,1.4 \mathrm{~Hz}), 5.84(1 \mathrm{H}, \mathrm{ddd}, J=17.2,10.6,6.6 \mathrm{~Hz}) ;{ }^{13} \mathrm{C}-\mathrm{NMR}$ $\left(125 \mathrm{MHz} \mathrm{CDCl}_{3}\right) \delta:$ 13.96, 20.05, 20.32, 22.18, 37.46, 39.73, 39.90, 50.73, 50.92, 51.67, 52.62, 115.07, 140.04, 156.76, 171.64; IR (neat): 1101, 1363, 1443, 1696, $1740 \mathrm{~cm}^{-1}$; MS (EI): $\mathrm{m} / z$ $283\left(\mathrm{M}^{+}\right)$; HRMS (EI) Calcd for $\mathrm{C}_{15} \mathrm{H}_{25} \mathrm{NO}_{4} 283.1784\left(\mathrm{M}^{+}\right)$; Found 269.1780; $[\alpha]_{\mathrm{D}}{ }^{19}-31.4$ (c $\left.1.00, \mathrm{CHCl}_{3}\right)$.

3.1.6. Synthesis of (2S, 3S, 6R)-2-[(Methoxy-methyl-carbamoyl)-methyl]-6-propyl-3-vinyl -piperidine-1-carboxylic Acid Methyl Ester (7)

To a stirred solution of 6 (571 mg, $2.02 \mathrm{mmol})$ in $\mathrm{MeOH}(4.5 \mathrm{~mL})$ and $\mathrm{H}_{2} \mathrm{O}(1.5 \mathrm{~mL})$ was added $\mathrm{LiOH} \cdot \mathrm{H}_{2} \mathrm{O}(338 \mathrm{mg}, 8.06 \mathrm{mmol})$, and the resulting mixture was refluxed for $2 \mathrm{~h}$. After cooling, $\mathrm{MeOH}$ was evaporated, and the residue was acidified with $10 \% \mathrm{HCl}$ (aq.) $(3 \mathrm{~mL})$. The aqueous mixture was extracted with EtOAc $(3 \mathrm{~mL} \times 5)$. The organic extracts were combined, dried, and evaporated to give a yellow oil, which was used directly in the next step. To a stirred solution of the above oil in $\mathrm{CH}_{2} \mathrm{Cl}_{2}(7 \mathrm{~mL})$ was added 1,1-carbonyldiimidazole $(457 \mathrm{mg}, 2.82 \mathrm{mmol})$ at $0{ }^{\circ} \mathrm{C}$, and the reaction mixture was stirred for $30 \mathrm{~min}$. To the reaction mixture were added $\mathrm{MeO}(\mathrm{Me}) \mathrm{NH} \cdot \mathrm{HCl}(275 \mathrm{mg}, 2.82 \mathrm{mmol})$ and $\mathrm{Et}_{3} \mathrm{~N}(0.40 \mathrm{~mL}, 2.82 \mathrm{mmol})$ at $0{ }^{\circ} \mathrm{C}$, and the resulting mixture was stirred at room temperature for $16 \mathrm{~h}$. The solvent was evaporated, and the residue was chromatographed 
on $\mathrm{SiO}_{2}(10 \mathrm{~g}$, acetone $/ \mathrm{n}$-hexane $=1 / 7)$ to give $7(610 \mathrm{mg}, 1.95 \mathrm{mmol}, 97 \%$ in 2 steps $)$ as a colorless oil.

${ }^{1} \mathrm{H}-\mathrm{NMR}\left(500 \mathrm{MHz} \mathrm{CDCl}_{3}\right) \delta: 0.91(3 \mathrm{H}, \mathrm{t}, J=7.3 \mathrm{~Hz}), 1.16-1.43(4 \mathrm{H}, \mathrm{m}), 1.48(2 \mathrm{H}$, q, $J=6.0 \mathrm{~Hz}), 1.76-1.92(2 \mathrm{H}, \mathrm{m}), 2.37(1 \mathrm{H}, \mathrm{br}), 2.53-2.56(1 \mathrm{H}, \mathrm{m}), 2.80(1 \mathrm{H}, \mathrm{m}), 3.12(3 \mathrm{H}$, br), $3.65(3 \mathrm{H}, \mathrm{s}), 3.67(3 \mathrm{H}, \mathrm{s}), 4.12(1 \mathrm{H}, \mathrm{br}), 4.63(1 \mathrm{H}, \mathrm{br}), 5.04(1 \mathrm{H}, \mathrm{dd}, J=10.7,1.4 \mathrm{~Hz})$, $5.07(1 \mathrm{H}, \mathrm{dd}, J=17.2,1.4 \mathrm{~Hz}), 5.84(1 \mathrm{H}, \mathrm{ddd}, J=17.2,10.7,1.4 \mathrm{~Hz}) ;{ }^{13} \mathrm{C}-\mathrm{NMR}(125 \mathrm{MHz}$ $\left.\mathrm{CDCl}_{3}\right) \delta: 13.96,19.85,20.26,22.15,29.20,32.12,37.36,39.15,50.20,50.55,52.51,61.22,114.82$, 140.30, 156.75, 172.01; IR (neat): 1100, 1348, 1362, 1444, 1667, 1694, $1698 \mathrm{~cm}^{-1}$; MS (EI): $\mathrm{m} / \mathrm{z}$ $312\left(\mathrm{M}^{+}\right)$; HRMS (EI) Calcd for $\mathrm{C}_{16} \mathrm{H}_{28} \mathrm{~N}_{2} \mathrm{O}_{4} 312.2049\left(\mathrm{M}^{+}\right)$; Found 312.2046; $[\alpha]_{\mathrm{D}}{ }^{23}-36.0$ (c $\left.1.00, \mathrm{CHCl}_{3}\right)$.

3.1.7. Synthesis of (2S, 3S, 6R)-2-(2-Oxo-propyl)-6-propyl-3-vinyl-piperidine-1-carboxylic Acid Methyl Ester (8)

To a stirred solution of $7(188 \mathrm{mg}, 0.60 \mathrm{mmol})$ in THF $(3 \mathrm{~mL})$ was added a solution $\mathrm{MeMgBr}(0.91 \mathrm{M}$ in THF, $0.97 \mathrm{~mL}, 0.72 \mathrm{mmol})$ at $0{ }^{\circ} \mathrm{C}$, and the resulting mixture was stirred at $0{ }^{\circ} \mathrm{C}$ for $1 \mathrm{~h}$. The reaction was quenched with sat. $\mathrm{NH}_{4} \mathrm{Cl}$ (aq.) $(5 \mathrm{~mL}$ ). The layers were separated, and the aqueous layer was extracted with $\mathrm{CH}_{2} \mathrm{Cl}_{2}(5 \mathrm{~mL} \times 3)$. The organic layer and extracts were combined, dried, and evaporated to give a colorless oil, which was chromatographed on $\mathrm{SiO}_{2}(7 \mathrm{~g}$, acetone $/ n$-hexane $=1 / 7)$ to give 8 (160 mg, $0.60 \mathrm{mmol}$, $99 \%$ ) as a colorless oil.

${ }^{1} \mathrm{H}-\mathrm{NMR}\left(500 \mathrm{MHz} \mathrm{CDCl}_{3}\right)$ 8: $0.93(3 \mathrm{H}, \mathrm{t}, J=7.3 \mathrm{~Hz}), 1.19-1.62(6 \mathrm{H}, \mathrm{m}), 1.79-1.91$ $(2 \mathrm{H}, \mathrm{m}), 2.18(3 \mathrm{H}, \mathrm{s}), 2.24(1 \mathrm{H}, \mathrm{br}), 2.59-2.63(1 \mathrm{H}, \mathrm{dd}, J=12.0,2.8 \mathrm{~Hz}), 2.70-2.79(1 \mathrm{H}, \mathrm{dd}$, $J=12.0,8.4 \mathrm{~Hz}), 3.69(3 \mathrm{H}, \mathrm{s}), 4.12(1 \mathrm{H}, \mathrm{br}), 4.62-4.64(1 \mathrm{H}, \mathrm{m}), 5.07(1 \mathrm{H}, \mathrm{dd}, J=10.6,1.5 \mathrm{~Hz})$, $5.09(1 \mathrm{H}, \mathrm{dd}, J=17.2,1.5 \mathrm{~Hz}), 5.86(1 \mathrm{H}, \mathrm{ddd}, J=17.2,10.6,1.5 \mathrm{~Hz}) ;{ }^{13} \mathrm{C}-\mathrm{NMR}(125 \mathrm{MHz}$ $\left.\mathrm{CDCl}_{3}\right) \delta: 13.97,19.82,20.29,22.00,29.86,37.30,39.59,49.44,50.00,50.26,52.56,115.08$, 140.07, 156.74, 206.60; IR (neat): 1102, 1277, 1361, 1407, 1443, 1640, $1694 \mathrm{~cm}^{-1}$; MS (EI): $\mathrm{m} / z$ $267\left(\mathrm{M}^{+}\right)$; HRMS (EI) Calcd for $\mathrm{C}_{15} \mathrm{H}_{25} \mathrm{NO}_{3} 267.1834\left(\mathrm{M}^{+}\right)$; Found 267.1835; $[\alpha]_{\mathrm{D}}{ }^{19}-70.0$ (c $\left.1.00, \mathrm{CHCl}_{3}\right)$.

3.1.8. Synthesis of (2S, 3S, 6R)-3-Formyl-2-(2-oxo-propyl)-6-propyl-piperidine-1-carboxylic Acid Methyl Ester (9)

To a stirred solution of $8(368 \mathrm{mg}, 1.38 \mathrm{mmol})$ in 1,4-dioxane $(6 \mathrm{~mL})$ and $\mathrm{H}_{2} \mathrm{O}$ $(2 \mathrm{~mL})$ was added 2,6-lutidine $(0.32 \mathrm{~mL}, 2.75 \mathrm{mmol}), \mathrm{OsO}_{4}(2 \%$ aqueous solution, $1.7 \mathrm{~mL}$, $0.14 \mathrm{mmol})$ and $\mathrm{NaIO}_{4}(1.18 \mathrm{~g}, 5.51 \mathrm{mmol})$ at $0{ }^{\circ} \mathrm{C}$, and the resulting mixture was stirred at room temperature for $3 \mathrm{~h}$. The reaction was quenched with $10 \% \mathrm{Na}_{2} \mathrm{~S}_{2} \mathrm{O}_{3}$ in sat. $\mathrm{NaHCO}_{3}$ (aq.) $(10 \mathrm{~mL})$, and the aqueous mixture was diluted with $\mathrm{CH}_{2} \mathrm{Cl}_{2}$. The layers were separated, and the aqueous layer was extracted with $\mathrm{CH}_{2} \mathrm{Cl}_{2}(5 \mathrm{~mL} \times 3)$. The organic layer and extracts were combined; washed with brine, $10 \% \mathrm{HCl}$ (aq.), and brine, successively; dried; and evaporated to give a yellow oil, which was chromatographed on $\mathrm{SiO}_{2}(10 \mathrm{~g}$, acetone $/ n$-hexane $=1 / 10)$ to give $9(349 \mathrm{mg}, 1.29 \mathrm{mmol}, 94 \%)$ as a colorless oil .

${ }^{1} \mathrm{H}-\mathrm{NMR}\left(500 \mathrm{MHz} \mathrm{CDCl}_{3}\right) \delta: 0.90(3 \mathrm{H}, \mathrm{t}, J=7.3 \mathrm{~Hz}), 1.16-1.26(1 \mathrm{H}, \mathrm{m}), 1.26-1.36$ $(1 \mathrm{H}, \mathrm{m}), 1.38-1.57(4 \mathrm{H}, \mathrm{m}), 1.74-1.82(1 \mathrm{H}, \mathrm{m}), 1.93-1.99(1 \mathrm{H}, \mathrm{m}), 2.17(3 \mathrm{H}, \mathrm{s}), 2.37(1 \mathrm{H}, \mathrm{br})$, 2.70-2.80 (2H, m), $3.67(3 \mathrm{H}, \mathrm{s}), 4.06(1 \mathrm{H}, \mathrm{br}), 5.15(1 \mathrm{H}, \mathrm{br}), 9.66(1 \mathrm{H}, \mathrm{s}) ;{ }^{13} \mathrm{C}-\mathrm{NMR}(125 \mathrm{MHz}$ $\left.\mathrm{CDCl}_{3}\right) \delta: 13.94,14.37,20.22,23.39,30.15,36.61,45.10,48.19,48.90,49.93,52.74,156.29$, 202.79, 206.29; IR (neat): 1100, 1328, 1354, 1447, 1684, 1694, 1717, 2873, $2957 \mathrm{~cm}^{-1}$; MS (EI): $m / z 269\left(\mathrm{M}^{+}\right)$; HRMS (EI) Calcd for $\mathrm{C}_{14} \mathrm{H}_{23} \mathrm{NO}_{4} 269.1627\left(\mathrm{M}^{+}\right)$; Found 269.1629; $[\alpha]_{\mathrm{D}}{ }^{23}$ -114.8 (c 1.00, $\mathrm{CHCl}_{3}$ ).

3.1.9. Synthesis of $(2 R, 4 \mathrm{a} R, 8 \mathrm{a} S)$-7-Oxo-2-propyl-3,4,4a,7,8,8a-hexahydro-2H-quinoline-1 -carboxylic Acid Methyl Ester (10c)

To a stirred solution of $9(349 \mathrm{mg}, 1.30 \mathrm{mmol})$ in benzene $(30 \mathrm{~mL})$ was added DBU $(0.78 \mathrm{~mL}, 5.18 \mathrm{mmol})$ and MS $4 \AA$ (50 mg), and the resulting mixture was refluxed for $48 \mathrm{~h}$. After cooling, benzene was evaporated, and the residue was acidified with $10 \% \mathrm{HCl}$ (aq.) $(5 \mathrm{~mL})$. The aqueous mixture was extracted with EtOAc $(3 \mathrm{~mL} \times 5)$. The organic extracts 
were combined, dried, and evaporated to give a brown oil, which was chromatographed on $\mathrm{SiO}_{2}(25 \mathrm{~g}, \mathrm{EtOAc} / \mathrm{n}$-hexane $=1 / 10)$ to give $10 \mathrm{c}(235 \mathrm{mg}, 0.94 \mathrm{mmol}, 72 \%)$ as a yellow oil.

${ }^{1} \mathrm{H}-\mathrm{NMR}\left(500 \mathrm{MHz} \mathrm{CDCl}_{3}\right) \delta: 0.91(3 \mathrm{H}, \mathrm{t}, J=7.2 \mathrm{~Hz}), 1.24-1.41(2 \mathrm{H}, \mathrm{m}), 1.44-1.55$ $(2 \mathrm{H}, \mathrm{m}), 1.59(1 \mathrm{H}, \mathrm{td}, J=10.0,2.4 \mathrm{~Hz}), 1.67(1 \mathrm{H}, \mathrm{tdd}, J=10.0,4.8,2.4 \mathrm{~Hz}), 1.73-1.78(1 \mathrm{H}$, m), 1.78-1.83 (1H, m), 2.40-2.45 (1H, m), $2.61(2 \mathrm{H}, \mathrm{br}), 3.70(3 \mathrm{H}, \mathrm{s}), 4.25(1 \mathrm{H}, \mathrm{br}), 4.63(1 \mathrm{H}$, br), $6.13(1 \mathrm{H}, \mathrm{d}, J=9.7 \mathrm{~Hz}), 6.77(1 \mathrm{H}, \mathrm{dd}, J=9.7,5.7 \mathrm{~Hz}) ;{ }^{13} \mathrm{C}-\mathrm{NMR}\left(125 \mathrm{MHz} \mathrm{CDCl}_{3}\right)$ $\delta: 13.88,19.95,20.24,27.09,36.53,37.00,40.30,48.43,49.73,52.60,128.64,152.18,156.04$, 198.22; IR (neat): 771, 1089, 1115, 1246, 1275, 1314, 1444, 1685, $2934 \mathrm{~cm}^{-1}$; MS (EI): $\mathrm{m} / z$ $251\left(\mathrm{M}^{+}\right)$; HRMS (EI) Calcd for $\mathrm{C}_{14} \mathrm{H}_{21} \mathrm{NO}_{3} 251.1521\left(\mathrm{M}^{+}\right)$; Found $251.1522 ;[\alpha]_{\mathrm{D}}{ }^{24}+29.9$ (c $\left.1.00, \mathrm{CHCl}_{3}\right)$.

3.1.10. Synthesis of $(2 R, 4 \mathrm{a} R, 5 R, 8 \mathrm{a} R)$-5-Methyl-2-propyl-7-trifluoromethane-sulfonyloxy3,4,4a,5,8,8a-hexahydro-2H-quinoline-1-carboxylic Acid Methyl Ester (11)

To a stirred solution of $\mathrm{CuI}(147 \mathrm{mg}, 0.77 \mathrm{mmol})$ in $\mathrm{Et}_{2} \mathrm{O}(3 \mathrm{~mL})$ was added a solution of $\mathrm{MeLi}\left(1.17 \mathrm{M}\right.$ in $\left.\mathrm{Et}_{2} \mathrm{O}, 1.32 \mathrm{~mL}, 1.54 \mathrm{mmol}\right)$ at $-78{ }^{\circ} \mathrm{C}$, and the reaction mixture was warmed to $0{ }^{\circ} \mathrm{C}$ for $30 \mathrm{~min}$. The reaction mixture was recooled to $-78{ }^{\circ} \mathrm{C}$, and a solution of $10 \mathrm{c}(97 \mathrm{mg}, 0.39 \mathrm{mmol})$ in $\mathrm{Et}_{2} \mathrm{O}(3 \mathrm{~mL})$ was added to the reaction mixture. The reaction mixture was gradually warmed to $0{ }^{\circ} \mathrm{C}$, and then a solution of Comins' reagent (303 $\mathrm{mg}$, $0.77 \mathrm{mmol})$ in $\mathrm{Et}_{2} \mathrm{O}(3 \mathrm{~mL})$ was added to the reaction mixture. The resulting mixture was stirred at room temperature for $2 \mathrm{~h}$, and the reaction was quenched with sat. $\mathrm{NH}_{4} \mathrm{Cl}$ (aq.) (5 mL). The aqueous mixture was diluted with $\mathrm{CH}_{2} \mathrm{Cl}_{2}(5 \mathrm{~mL})$, and the resulting suspension was filtered. The filtrate was separated, and the aqueous layer was extracted with $\mathrm{CH}_{2} \mathrm{Cl}_{2}$ $(3 \mathrm{~mL} \times 3)$. The filtrate and extracts were combined, dried, and evaporated to give a colorless oil, which was chromatographed on $\mathrm{SiO}_{2}(10 \mathrm{~g}$, acetone/ $n$-hexane $=1 / 50)$ to give 11 (144 mg, $0.36 \mathrm{mmol}, 94 \%$ ) as a colorless oil.

${ }^{1} \mathrm{H}-\mathrm{NMR}\left(400 \mathrm{MHz} \mathrm{CDCl}_{3}\right) \delta: 0.90(3 \mathrm{H}, \mathrm{t}, J=7.2 \mathrm{~Hz}), 1.12(3 \mathrm{H}, \mathrm{d}, J=7.2 \mathrm{~Hz}), 1.19-1.39$ $(4 \mathrm{H}, \mathrm{m}), 1.39-1.50(1 \mathrm{H}, \mathrm{m}), 1.50-1.72(4 \mathrm{H}, \mathrm{m}), 2.26(1 \mathrm{H}, \mathrm{t}, J=6.0 \mathrm{~Hz}), 2.50(2 \mathrm{H}, \mathrm{br}), 3.69(3 \mathrm{H}$, s), $4.10(1 \mathrm{H}, \mathrm{br}), 4.50(1 \mathrm{H}, \mathrm{br}), 5.66(1 \mathrm{H}, \mathrm{d}, J=6.0 \mathrm{~Hz}) ;{ }^{13} \mathrm{C}-\mathrm{NMR}\left(100 \mathrm{MHz} \mathrm{CDCl}_{3}\right) \delta: 13.83$, $19.15,20.68,21.49,27.88,29.67,35.23,38.04,40.26,46.91,50.41,52.63,118.45$ (q, J = 318.5 Hz), 121.19, 144.70, 156.65; IR (neat): 1144, 1209, 1246, 1419, 1445, 1699, 2936, $2959 \mathrm{~cm}^{-1}$; MS (EI): $m / z 399\left(\mathrm{M}^{+}\right)$; HRMS (EI) Calcd for $\mathrm{C}_{16} \mathrm{H}_{24} \mathrm{~F}_{3} \mathrm{NO}_{5} \mathrm{~S} 399.1327\left(\mathrm{M}^{+}\right)$; Found 399.1337; $[\alpha]_{\mathrm{D}}{ }^{23}$ $+58.6\left(\right.$ c $\left.1.35, \mathrm{CHCl}_{3}\right)$.

3.1.11. Synthesis of $(2 R, 4 \mathrm{a} R, 5 R, 8 \mathrm{a} R)$-5-Methyl-2-propyl-octahydro-quinoline-1-carboxylic Acid Methyl Ester (12)

To a stirred solution of $11(60 \mathrm{mg}, 0.15 \mathrm{mmol})$ in $\mathrm{MeOH}(3 \mathrm{~mL})$ was added 20\% $\mathrm{Pd}(\mathrm{OH})_{2} / \mathrm{C}(5 \mathrm{mg})$, and the resulting mixture was hydrogenated at $1 \mathrm{~atm}$ for $16 \mathrm{~h}$. The catalyst was removed through a celite pad and washed with $\mathrm{MeOH}(3 \mathrm{~mL} \times 3)$. The filtrate and washings were combined and evaporated to give a pale yellow oil, which was chromatographed on $\mathrm{SiO}_{2}(8 \mathrm{~g}$, acetone $/ n$-hexane $=1 / 30)$ to give $12(33 \mathrm{mg}, 0.13 \mathrm{mmol}$, $88 \%$ ) as a colorless oil.

${ }^{1} \mathrm{H}-\mathrm{NMR}\left(500 \mathrm{MHz} \mathrm{CDCl}_{3}\right) \delta: 0.90(3 \mathrm{H}, \mathrm{t}, J=7.2 \mathrm{~Hz}), 1.06(3 \mathrm{H}, \mathrm{d}, J=6.9 \mathrm{~Hz}), 1.17-1.68$ $(14 \mathrm{H}, \mathrm{m}), 1.79-1.88(2 \mathrm{H}, \mathrm{m}), 3.70(3 \mathrm{H}, \mathrm{s}), 4.06(1 \mathrm{H}, \mathrm{br}), 4.22(1 \mathrm{H}, \mathrm{br}) ;{ }^{13} \mathrm{C}-\mathrm{NMR}(125 \mathrm{MHz}$ $\left.\mathrm{CDCl}_{3}\right) \delta: 14.17,19.41,20.41,20.72,21.36,26.82,28.19,28.57,34.61,37.81,42.19,49.81,50.49$, 52.36, 156.65; IR (neat): 1303, 1317, 1443, 1695, 2864, 2929, $2955 \mathrm{~cm}^{-1}$; MS (EI) $\mathrm{m} / z 253$ $\left(\mathrm{M}^{+}\right)$; HRMS (EI) Calcd for $\mathrm{C}_{15} \mathrm{H}_{27} \mathrm{NO}_{2} 253.2042\left(\mathrm{M}^{+}\right)$; Found 253.2043; $[\alpha]_{\mathrm{D}}{ }^{17}-20.2(c$ 1.00, $\left.\mathrm{CHCl}_{3}\right)$.

3.1.12. Synthesis of $(2 R, 4 \mathrm{a} R, 5 R, 8 \mathrm{a} R)$-5-Methyl-2-propyldecahydroquinoline (ent-cis-195A)

To a stirred solution of $12(42 \mathrm{mg}, 0.17 \mathrm{mmol})$ in $\mathrm{CHCl}_{3}(3 \mathrm{~mL})$ was added $\mathrm{NaI}$ $(197 \mathrm{mg}, 1.32 \mathrm{mmol})$ and TMSCl $(0.10 \mathrm{~mL}, 0.83 \mathrm{mmol})$, and the resulting mixture was heated to $50{ }^{\circ} \mathrm{C}$ for $24 \mathrm{~h}$. After cooling, the reaction was quenched with $10 \% \mathrm{Na}_{2} \mathrm{~S}_{2} \mathrm{O}_{3}$ in sat. $\mathrm{NaHCO}_{3}$ (aq.) (3 mL), and aqueous mixture was extracted with $\mathrm{CH}_{2} \mathrm{Cl}_{2}(2 \mathrm{~mL} \times 10)$. 
The organic extracts were combined, dried, and evaporated to give a pale yellow oil, which was chromatographed on $\mathrm{SiO}_{2}\left(3 \mathrm{~g}, \mathrm{MeOH} / \mathrm{CH}_{2} \mathrm{Cl}_{2}=1 / 20\right)$ to give ent-cis-195A (30 mg, $0.15 \mathrm{mmol}, 88 \%$ ) as a pale yellow oil. ent-cis-195A $\cdot \mathrm{HCl}$ was obtained in quantitative yield by treatment with $\mathrm{HCl}$ (ca. $1 \mathrm{~mol} / \mathrm{L}_{\text {in }} \mathrm{Et}_{2} \mathrm{O}$ ) followed by evaporation.

ent-cis-195A: ${ }^{1} \mathrm{H}-\mathrm{NMR}\left(400 \mathrm{MHz} \mathrm{CDCl}_{3}\right) \delta: 0.83(3 \mathrm{H}, \mathrm{d}, J=6.6 \mathrm{~Hz}), 0.90(3 \mathrm{H}, \mathrm{t}$, $J=7.0 \mathrm{~Hz}), 0.95-1.02(1 \mathrm{H}, \mathrm{m}), 1.03-1.14(2 \mathrm{H}, \mathrm{m}), 1.25-1.49(8 \mathrm{H}, \mathrm{m}), 1.52-1.70(4 \mathrm{H}, \mathrm{m}), 1.79-$ $1.90(1 \mathrm{H}, \mathrm{m}), 1.90-1.97(1 \mathrm{H}, \mathrm{m}), 2.53(1 \mathrm{H}, \mathrm{dtd}, J=11.4,5.8,2.8 \mathrm{~Hz}), 2.84(1 \mathrm{H}, \mathrm{q}, J=2.8 \mathrm{~Hz})$; ${ }^{13} \mathrm{C}-\mathrm{NMR}\left(100 \mathrm{MHz} \mathrm{CDCl}_{3}\right)$ ): 14.30, 19.14, 19.91, 21.21, 26.99, 27.24, 27.35, 33.28, 35.88, 39.59, 42.49, 55.96, 57.72; IR (neat): 857, 890, 962, 1024, 1044, 1081, 1124, 1167, 1256, 1317, $1348,1380,1451,1734,2803,2873,2935 \mathrm{~cm}^{-1}$; MS (EI) $\mathrm{m} / z 195\left(\mathrm{M}^{+}\right)$; HRMS (EI) Calcd for $\mathrm{C}_{13} \mathrm{H}_{25} \mathrm{~N} 195.1987\left(\mathrm{M}^{+}\right)$; Found 195.1985; ent-cis-195A $\cdot \mathrm{HCl}:[\alpha]_{\mathrm{D}}^{20}+12.7($ c 0.35, $\mathrm{MeOH})$.

The ${ }^{1} \mathrm{H}$ - and ${ }^{13} \mathrm{C}-\mathrm{NMR}$ spectra and optical rotation of the synthetic sample were identical with those of the literature data.

${ }^{1} \mathrm{H}-\mathrm{NMR}\left(500 \mathrm{MHz} \mathrm{CDCl}_{3}\right) \delta: 0.83(3 \mathrm{H}, \mathrm{d}, J=6.6 \mathrm{~Hz}), 0.90(3 \mathrm{H}, \mathrm{t}, J=7.0 \mathrm{~Hz}), 0.94-1.03$ $(1 \mathrm{H}, \mathrm{m}), 1.05-1.14(2 \mathrm{H}, \mathrm{m}), 1.22-1.49(9 \mathrm{H}, \mathrm{m}), 1.50-1.71(4 \mathrm{H}, \mathrm{m}), 1.77-1.90(1 \mathrm{H}, \mathrm{m}), 1.90-1.99$ $(1 \mathrm{H}, \mathrm{m}), 2.53(1 \mathrm{H}, \mathrm{dtd}, \mathrm{J}=11.4,5.8,2.7 \mathrm{~Hz}), 2.84(1 \mathrm{H}, \mathrm{q}, J=2.8 \mathrm{~Hz}) ;{ }^{13} \mathrm{C}-\mathrm{NMR}(75 \mathrm{MHz}$ $\left.\mathrm{CDCl}_{3}\right)$ 8: $14.5\left(\mathrm{CH}_{3}\right), 19.3\left(\mathrm{CH}_{2}\right), 20.1\left(\mathrm{CH}_{3}\right), 21.4\left(\mathrm{CH}_{2}\right), 27.2\left(\mathrm{CH}_{2}\right), 27.54(\mathrm{CH}), 27.55$ $\left(\mathrm{CH}_{2}\right), 33.6\left(\mathrm{CH}_{2}\right), 36.1\left(\mathrm{CH}_{2}\right), 39.9\left(\mathrm{CH}_{2}\right), 42.8(\mathrm{CH}), 56.1(\mathrm{CH}), 57.9(\mathrm{CH})$; ent-cis-195A-HCl: $[\alpha]_{\mathrm{D}}^{20}+12.9(c 0.36, \mathrm{MeOH})[22]$.

3.1.13. Synthesis of $(2 R, 4 a R, 5 R, 8 \mathrm{a} R)$-5-Methyl-2-propyl-3,4,4a,5,8,8a-hexahydro-2Hquinoline-1-carboxylic Acid Methyl Ester (13)

To a stirred solution of $\mathbf{1 1}(144 \mathrm{mg}, 0.36 \mathrm{mmol})$ in THF $(3 \mathrm{~mL})$ was added $\mathrm{PPh}_{3}(7 \mathrm{mg}$, $0.03 \mathrm{mmol})$ and $\mathrm{Pd}(\mathrm{OAc})_{2}(3 \mathrm{mg}, 0.01 \mathrm{mmol})$ at room temperature, and the reaction mixture was heated to $25^{\circ} \mathrm{C}$ for $10 \mathrm{~min}$. A solution of $\mathrm{Et}_{3} \mathrm{~N}(0.11 \mathrm{~mL}, 0.81 \mathrm{mmol})$ and formic acid $(0.03 \mathrm{~mL}, 0.80 \mathrm{mmol})$ in THF $(1 \mathrm{~mL})$ was added to the reaction mixture, and the resulting mixture was refluxed for $18 \mathrm{~h}$. The reaction was quenched with brine $(5 \mathrm{~mL})$. The layers were separated, and the aqueous layer was extracted with $\mathrm{CH}_{2} \mathrm{Cl}_{2}(3 \mathrm{~mL} \times 3)$. The organic layer and extracts were combined, dried, and evaporated to give a colorless oil, which was chromatographed on $\mathrm{SiO}_{2}(8 \mathrm{~g}$, acetone $/ n$-hexane $=1 / 50)$ to give $13(85 \mathrm{mg}, 0.36 \mathrm{mmol}$, $100 \%)$ as a colorless oil.

${ }^{1} \mathrm{H}-\mathrm{NMR}\left(400 \mathrm{MHz} \mathrm{CDCl}_{3}\right) \delta: 0.89(3 \mathrm{H}, \mathrm{t}, J=7.2 \mathrm{~Hz}), 1.05(3 \mathrm{H}, \mathrm{d}, J=6.4 \mathrm{~Hz}), 1.23-1.66$ $(9 \mathrm{H}, \mathrm{m}), 2.03(1 \mathrm{H}, \mathrm{m}), 2.15(2 \mathrm{H}, \mathrm{m}), 3.67(3 \mathrm{H}, \mathrm{s}), 4.07(1 \mathrm{H}, \mathrm{br}), 4.35(1 \mathrm{H}, \mathrm{br}), 5.44-5.53(2 \mathrm{H}$, $\mathrm{m}) ;{ }^{13} \mathrm{C}-\mathrm{NMR}\left(100 \mathrm{MHz} \mathrm{CDCl}_{3}\right) \delta: 14.02,20.77,21.96,22.42,27.34,28.21,29.67,37.03,41.33$, 47.11, 50.53, 52.33, 122.82, 130.53, 156.39; IR (neat): 1093, 1304, 1320, 1444, 1695, 2871, 2930, $2955 \mathrm{~cm}^{-1}$; MS (EI) $\mathrm{m} / z 251\left(\mathrm{M}^{+}\right)$; HRMS (EI) Calcd for $\mathrm{C}_{15} \mathrm{H}_{25} \mathrm{NO}_{2} 251.1885\left(\mathrm{M}^{+}\right)$; Found 251.1877; $[\alpha]_{\mathrm{D}}^{23}+57.4\left(\right.$ c $\left.0.90, \mathrm{CHCl}_{3}\right)$.

3.1.14. Synthesis of $(2 R, 4 a R, 5 R, 6 R, 8 a R)-6$-Hydroxy-5-methyl-2-propyl-octahydroquinoline-1-carboxylic Acid Methyl Ester (15)

To a stirred solution of $\mathbf{1 3}(18 \mathrm{mg}, 0.08 \mathrm{mmol})$ in toluene $(1.5 \mathrm{~mL})$ was added $\mathrm{BH}_{3} \cdot \mathrm{SMe}_{2}$ $(0.02 \mathrm{~mL}, 0.23 \mathrm{mmol})$ at $0{ }^{\circ} \mathrm{C}$. The reaction mixture was stirred at room temperature for $24 \mathrm{~h}$ and then cautiously quenched with $10 \% \mathrm{NaOH}(0.25 \mathrm{~mL})$ at $0{ }^{\circ} \mathrm{C}$, followed by the slow addition of $\mathrm{H}_{2} \mathrm{O}_{2}(30 \%, 0.25 \mathrm{~mL})$ at $0{ }^{\circ} \mathrm{C}$. The reaction mixture was stirred at room temperature for $24 \mathrm{~h}$. The layers were separated, and the aqueous layer was extracted with $\mathrm{CH}_{2} \mathrm{Cl}_{2}(3 \mathrm{~mL} \times 3)$. The organic layer and extracts were combined, dried, and evaporated to give a colorless oil, which was chromatographed on $\mathrm{SiO}_{2}(5 \mathrm{~g}$, acetone $/ n$-hexane $=1 / 10)$ to give $15(10 \mathrm{mg}, 0.04 \mathrm{mmol}, 50 \%)$ as a colorless oil and the inseparable mixture of alcohols 16 and 17 (9 mg, $0.03 \mathrm{mmol}, 45 \%)$ as a colorless oil.

15: ${ }^{1} \mathrm{H}-\mathrm{NMR}\left(400 \mathrm{MHz} \mathrm{CDCl}_{3}\right) \delta: 0.91(3 \mathrm{H}, \mathrm{t}, J=7.6 \mathrm{~Hz}), 1.05(3 \mathrm{H}, \mathrm{d}, J=7.6 \mathrm{~Hz})$, 1.20-1.26 (1H, m), 1.28-1.36 (2H, m), 1.46-1.68 (7H, m), $1.78(1 \mathrm{H}, \mathrm{qdd}, J=14.3,3.9,2.8 \mathrm{~Hz})$, $1.88(1 \mathrm{H}, \mathrm{qd}, J=7.6,1.7 \mathrm{~Hz}), 2.01(1 \mathrm{H}, \mathrm{qd}, J=13.2,3.9 \mathrm{~Hz}), 2.28(1 \mathrm{H}, \mathrm{qd}, J=13.6,3.2 \mathrm{~Hz})$, $3.67(3 \mathrm{H}, \mathrm{s}), 4.02-4.10(1 \mathrm{H}, \mathrm{m}), 4.18-4.25(1 \mathrm{H}, \mathrm{m}) ;{ }^{13} \mathrm{C}-\mathrm{NMR}\left(100 \mathrm{MHz} \mathrm{CDCl}_{3}\right)$ 8: 14.05, 18.89, 20.56, 22.77, 28.35, 28.64, 29.68, 37.33, 41.32, 41.87, 49.86, 50.51, 52.32, 70.97, 156.69; IR (neat): 
1319, 1447, 1456, 1670, 1697, 2872, 2934, $2957 \mathrm{~cm}^{-1}$; MS (EI) $\mathrm{m} / z 269\left(\mathrm{M}^{+}\right)$; HRMS (EI) Calcd for $\mathrm{C}_{15} \mathrm{H}_{27} \mathrm{NO}_{3} 269.1991\left(\mathrm{M}^{+}\right)$; Found 269.1990; $[\alpha]_{\mathrm{D}}^{25}-17.1$ (c 0.80, $\left.\mathrm{CHCl}_{3}\right)$.

3.1.15. Synthesis of $(2 R, 4 \mathrm{a} R, 5 R, 8 \mathrm{a} R)$-5-Methyl-6-oxo-2-propyl-octahydro-quinoline-1 -carboxylic Acid Methyl Ester (19)

To a stirred solution of $15(46 \mathrm{mg}, 0.17 \mathrm{mmol})$ in $\mathrm{CH}_{2} \mathrm{Cl}_{2}(1.5 \mathrm{~mL})$ and sat. $\mathrm{NaHCO}_{3}$ (aq.) $(1.5 \mathrm{~mL})$ was added $\mathrm{NaOCl} \cdot 5 \mathrm{H}_{2} \mathrm{O}(55 \mathrm{mg}, 0.34 \mathrm{mmol})$ and $\mathrm{AZADOL}^{\circledR}(0.3 \mathrm{mg}$, $0.0017 \mathrm{mmol}$ ) at $0{ }^{\circ} \mathrm{C}$, and the resulting mixture was stirred at room temperature for $1 \mathrm{~h}$. The layers were separated, and the aqueous layer was extracted with $\mathrm{CH}_{2} \mathrm{Cl}_{2}(1 \mathrm{~mL} \times 3)$. The organic layer and extracts were combined, dried, and evaporated to give a yellow oil, which was chromatographed on $\mathrm{SiO}_{2}(8 \mathrm{~g}$, acetone $/ n$-hexane $=1 / 5)$ to give $19(43 \mathrm{mg}$, $0.16 \mathrm{mmol}, 98 \%$ ) as pale yellow oil.

${ }^{1} \mathrm{H}-\mathrm{NMR}\left(400 \mathrm{MHz} \mathrm{CDCl}_{3}\right) \delta: 0.88(3 \mathrm{H}, \mathrm{t}, J=6.8 \mathrm{~Hz}), 1.24(3 \mathrm{H}, \mathrm{d}, J=7.6 \mathrm{~Hz}), 1.26-1.69$ $(8 \mathrm{H}, \mathrm{m}), 1.76-1.84(1 \mathrm{H}, \mathrm{m}), 1.92-2.00(1 \mathrm{H}, \mathrm{m}), 2.06(1 \mathrm{H}, \mathrm{qd}, J=12.8,4.8 \mathrm{~Hz}), 2.16-2.22(1 \mathrm{H}$, m), 2.26-2.33 $(1 \mathrm{H}, \mathrm{m}), 2.60(1 \mathrm{H}, \mathrm{td}, J=14.8,6.8 \mathrm{~Hz}), 3.69(3 \mathrm{H}, \mathrm{s}), 4.05-4.12(1 \mathrm{H}, \mathrm{m}), 4.58-4.61$ $(1 \mathrm{H}, \mathrm{m}) ;{ }^{13} \mathrm{C}-\mathrm{NMR}\left(100 \mathrm{MHz} \mathrm{CDCl}_{3}\right) \delta: 13.99,17.20,20.53,21.91,27.40,27.53,29.68,36.94$, $37.45,43.75,48.89,50.12,50.45,52.58,156.57,213.93$; IR (neat): 1093, 1133, 1189, 1244, 1275, 1312, 1348, 1409, 1444, 1699, 1717, 2855, 2929, $2954 \mathrm{~cm}^{-1}$; MS (EI) $\mathrm{m} / z 267\left(\mathrm{M}^{+}\right)$; HRMS (EI) Calcd for $\mathrm{C}_{15} \mathrm{H}_{25} \mathrm{NO}_{3}$ 267.1834 $\left(\mathrm{M}^{+}\right)$; Found 267.1834; $[\alpha]_{\mathrm{D}}{ }^{25}$-21.4 (c 0.50, $\left.\mathrm{CHCl}_{3}\right)$.

3.1.16. Synthesis of $(2 R, 4 \mathrm{a} R, 5 R, 6 \mathrm{~S}, 8 \mathrm{a} R)$-6-Hydroxy-5-methyl-2-propyl-octahydroquinoline-1-carboxylic Acid Methyl Ester (16)

To a stirred solution of $\mathbf{1 9}(18 \mathrm{mg}, 0.07 \mathrm{mmol})$ in THF $(2 \mathrm{~mL})$ was added a solution of Super-Hydride ${ }^{\circledR}(1.0 \mathrm{M}$ in THF, $0.20 \mathrm{~mL}, 0.20 \mathrm{mmol})$ at $0{ }^{\circ} \mathrm{C}$, and the resulting mixture was stirred at room temperature for $1 \mathrm{~h}$. The reaction was quenched with sat. $\mathrm{NH}_{4} \mathrm{Cl}$ (aq.) $(2 \mathrm{~mL})$. The layers were separated, and the aqueous layer was extracted with $\mathrm{CH}_{2} \mathrm{Cl}_{2}$ $(1 \mathrm{~mL} \times 3)$. The organic layer and extracts were combined, dried, and evaporated to give a colorless oil, which was chromatographed on $\mathrm{SiO}_{2}(5 \mathrm{~g}$, acetone $/ n$-hexane $=1 / 5)$ to give $\mathbf{1 6}$ (16 mg, $0.06 \mathrm{mmol}, 89 \%)$ as a colorless oil and $15(2 \mathrm{mg}, 0.01 \mathrm{mmol}, 11 \%)$ as a colorless oil.

${ }^{1} \mathrm{H}-\mathrm{NMR}\left(400 \mathrm{MHz} \mathrm{CDCl}_{3}\right) \delta: 0.91(3 \mathrm{H}, \mathrm{t}, J=7.2 \mathrm{~Hz}), 1.06(3 \mathrm{H}, \mathrm{d}, J=7.2 \mathrm{~Hz}), 1.23-1.71$ $(13 \mathrm{H}, \mathrm{m}), 1.83(1 \mathrm{H}, \mathrm{qd}, J=13.6,2.8 \mathrm{~Hz}), 1.99(1 \mathrm{H}, \mathrm{t}, J=6.0 \mathrm{~Hz}), 3.68(3 \mathrm{H}, \mathrm{s}), 4.02-4.11(1 \mathrm{H}$, m), 4.19-4.29 (1H, m); ${ }^{13} \mathrm{C}-\mathrm{NMR}\left(100 \mathrm{MHz} \mathrm{CDCl}_{3}\right) \delta: 12.22,14.03,20.58,21.03,28.12,28.64$, 29.68, 37.58, 40.53, 43.06, 48.75, 50.33, 52.38, 68.66, 156.63; IR (neat): 1097, 1319, 1448, 1670, 2870, 2932, $2955 \mathrm{~cm}^{-1}$; MS (EI) $\mathrm{m} / z 269\left(\mathbf{M}^{+}\right)$; HRMS (EI) Calcd for $\mathrm{C}_{15} \mathrm{H}_{27} \mathrm{NO}_{3} 269.1991$ $\left(\mathrm{M}^{+}\right)$; Found 269.1990; $[\alpha]_{\mathrm{D}}{ }^{25}-16.5\left(\mathrm{c} 0.50, \mathrm{CHCl}_{3}\right)$.

3.1.17. Synthesis of $(2 R, 4 a R, 5 R, 6 S, 8 a R)$-5-Methyl-2-propyldecahydroquinoline-6-ol (cis-211A)

To a stirred solution of $\mathbf{1 6}(15 \mathrm{mg}, 0.06 \mathrm{mmol})$ in $\mathrm{MeCN}(2 \mathrm{~mL})$ was added $\mathrm{NaI}(67 \mathrm{mg}$, $0.45 \mathrm{mmol})$ and TMSCl $(0.04 \mathrm{~mL}, 0.28 \mathrm{mmol})$, and the resulting mixture was refluxed for $1 \mathrm{~h}$. After cooling, the reaction was quenched with $10 \% \mathrm{Na}_{2} \mathrm{~S}_{2} \mathrm{O}_{3}$ in sat. $\mathrm{NaHCO}_{3}$ (aq.) (2 mL). The layers were separated, and the aqueous layer was extracted with $\mathrm{CH}_{2} \mathrm{Cl}_{2}(1 \mathrm{~mL} \times 10)$. The organic layer and extracts were combined, dried, and evaporated to give a pale yellow oil, which was chromatographed on $\mathrm{SiO}_{2}\left(3 \mathrm{~g}, \mathrm{MeOH} / \mathrm{CH}_{2} \mathrm{Cl}_{2}=1 / 5\right)$ to give cis-211A (13 $\mathrm{mg}, 0.06 \mathrm{mmol}, 100 \%$ ) as pale yellow oil.

${ }^{1} \mathrm{H}-\mathrm{NMR}\left(400 \mathrm{MHz} \mathrm{CDCl}_{3}\right) \delta: 0.90(3 \mathrm{H}, \mathrm{t}, J=6.4 \mathrm{~Hz}), 0.95(3 \mathrm{H}, \mathrm{d}, J=6.8 \mathrm{~Hz}), 1.10-1.18$ $(2 \mathrm{H}, \mathrm{m}), 1.27-1.45(6 \mathrm{H}, \mathrm{m}), 1.54-1.66(3 \mathrm{H}, \mathrm{m}), 1.80-1.87(1 \mathrm{H}, \mathrm{m}), 1.91-2.03(2 \mathrm{H}, \mathrm{m}), 2.06-2.15$ $(1 \mathrm{H}, \mathrm{m}), 2.53-2.62(1 \mathrm{H}, \mathrm{m}), 2.89(1 \mathrm{H}, \mathrm{br}), 3.83(1 \mathrm{H}, \mathrm{br}) ;{ }^{13} \mathrm{C}-\mathrm{NMR}\left(100 \mathrm{MHz} \mathrm{CDCl}_{3}\right) \delta: 14.22$, $15.82,19.09,26.37,26.45,28.08,29.68,31.02,34.55,39.09,55.94,57.95,72.11$; IR (neat): 753, 812, 883, 946, 997, 1029, 1100, 1158, 1191, 1257, 1317, 1339, 1376, 1444, 2806, 2879, 2934, $3659 \mathrm{~cm}^{-1}$; MS (EI) $m / z 211\left(\mathrm{M}^{+}\right)$; HRMS (EI) Calcd for $\mathrm{C}_{13} \mathrm{H}_{25} \mathrm{NO} 211.1936\left(\mathrm{M}^{+}\right)$; Found 211.1943; $[\alpha]_{\mathrm{D}}{ }^{25}-11.5\left(c 1.00, \mathrm{CHCl}_{3}\right)$.

The ${ }^{1} \mathrm{H}$ - and ${ }^{13} \mathrm{C}$-NMR spectra and optical rotation of the synthetic sample were identical with those of the literature data. 
${ }^{1} \mathrm{H}-\mathrm{NMR}\left(400 \mathrm{MHz} \mathrm{CDCl}_{3}\right) \delta: 0.90(3 \mathrm{H}, \mathrm{t}), 0.95(3 \mathrm{H}, \mathrm{d}), 1.06-1.16(2 \mathrm{H}, \mathrm{m}), 1.29-1.43$ $(6 \mathrm{H}, \mathrm{m}), 1.56-1.67(3 \mathrm{H}, \mathrm{m}), 1.81-1.87(1 \mathrm{H}, \mathrm{m}), 1.91-2.03$ (2H, m), 2.06-2.15 (1H, m), 2.53-2.61

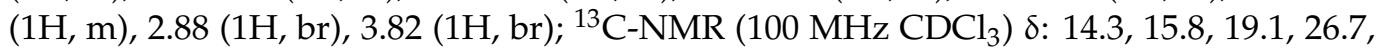
$26.8,26.9,28.9,31.1,34.9,39.3,55.8,57.8,72.3 ;[\alpha]_{\mathrm{D}}^{25}-11.7$ (c 1.00, $\left.\mathrm{CHCl}_{3}\right)$ [23].

3.1.18. Synthesis of $(2 R, 4 \mathrm{a} R, 5 R, 6 R, 8 \mathrm{a} R)$-5-Methyl-2-propyldecahydroquinoline-6-ol (6-epi-211A)

To a stirred solution of $\mathbf{1 5}(18 \mathrm{mg}, 0.07 \mathrm{mmol})$ in $\mathrm{MeCN}(2 \mathrm{~mL})$ was added NaI $(80 \mathrm{mg}$, $0.54 \mathrm{mmol})$ and $\mathrm{TMSCl}(0.04 \mathrm{~mL}, 0.33 \mathrm{mmol})$, and the resulting mixture was refluxed for $1 \mathrm{~h}$. After cooling, the reaction was quenched with $10 \% \mathrm{Na}_{2} \mathrm{~S}_{2} \mathrm{O}_{3}$ in sat. $\mathrm{NaHCO}_{3}$ (aq.) (2 mL). The layers were separated, and the aqueous layer was extracted with $\mathrm{CH}_{2} \mathrm{Cl}_{2}(1 \mathrm{~mL} \times 10)$. The organic layer and extracts were combined, dried, and evaporated to give a pale yellow oil, which was chromatographed on $\mathrm{SiO}_{2}\left(3 \mathrm{~g}, \mathrm{MeOH} / \mathrm{CH}_{2} \mathrm{Cl}_{2}=1 / 5\right)$ to give 6-epi-211A (10 $\mathrm{mg}, 0.05 \mathrm{mmol}, 72 \%)$ as pale yellow oil.

${ }^{1} \mathrm{H}-\mathrm{NMR}\left(400 \mathrm{MHz} \mathrm{CDCl}_{3}\right) \delta: 0.95(3 \mathrm{H}, \mathrm{t}, J=7.2 \mathrm{~Hz}), 1.03-1.05(1 \mathrm{H}, \mathrm{m}), 1.07(3 \mathrm{H}$, $\mathrm{d}, J=6.0 \mathrm{~Hz}), 1.31-1.60(5 \mathrm{H}, \mathrm{m}), 1.68-1.82(2 \mathrm{H}, \mathrm{m}), 1.87-2.08(4 \mathrm{H}, \mathrm{m}), 2.14-2.20(1 \mathrm{H}, \mathrm{m})$, 2.36-2.40 (1H, m), $3.11(1 \mathrm{H}, \mathrm{m}), 3.29(1 \mathrm{H}, \mathrm{br}), 3.34(1 \mathrm{H}, \mathrm{td}, J=9.2,3.6 \mathrm{~Hz})$; ${ }^{13} \mathrm{C}-\mathrm{NMR}$ $\left(100 \mathrm{MHz} \mathrm{CDCl}_{3}\right) \delta: 13.84,15.11,19.01,23.91,25.14,27.48,28.89,35.47,36.00,39.18,57.06$, 59.69, 74.85; IR (neat): 1375, 1456, 1636, 1647, 2866, 2926, 2955, $3647 \mathrm{~cm}^{-1}$; MS (EI) $\mathrm{m} / \mathrm{z}$ $211\left(\mathrm{M}^{+}\right)$; HRMS (EI) Calcd for $\mathrm{C}_{13} \mathrm{H}_{25} \mathrm{NO}$ : $211.1936\left(\mathrm{M}^{+}\right)$; Found 211.1928; $[\alpha]_{\mathrm{D}}{ }^{20}-5.3$ (c $0.4, \mathrm{CHCl}_{3}$ )

\subsection{Electrophysiological Recording of Nicotinic ACh Receptor-Mediated Current in Xenopus Oocytes}

Xenopus oocytes expressing recombinant mouse $\alpha 7$ - and $\alpha 4 \beta 2$-nicotinic ACh receptors were prepared by injection of the plasmid containing respective subunit cDNAs (provided by Dr. J. A. Stitzel, University of Michigan Medical Center), according to the protocols described previously [29]. The oocytes were cultured at $19{ }^{\circ} \mathrm{C}$ for 3 to 6 days in $50 \%$ Leibovitz's L-15 Medium (11415064, Thermo Fisher Scientific, Waltham, MA, USA, pH 7.5) containing $1 \mu \mathrm{g} / \mathrm{mL}$ insulin and $100 \mu \mathrm{g} / \mathrm{mL}$ gentamicin (078-06061, Fujifilm Wako Pure Chemical Corp., Osaka, Japan). Two-electrode voltage-clamp recordings were then performed, as described previously [29]. In brief, an oocyte was placed in a $300 \mu \mathrm{L}$ tube-like chamber where Ringer solution ( $82.5 \mathrm{mM} \mathrm{NaCl}, 2.5 \mathrm{mM} \mathrm{KCl}, 2.5 \mathrm{mM} \mathrm{CaCl}_{2}, 1 \mathrm{mM} \mathrm{MgCl}$, and $5 \mathrm{mM}$ HEPES, pH 7.4) containing $1 \mu \mathrm{M}$ atropine (A0257, Sigma-Aldrich, MA, USA) was perfused at a rate of $15 \mathrm{~mL} / \mathrm{min}$. Membrane potential was held at $-60 \mathrm{mV}$, and currents were measured using a GeneClamp 500 amplifier, Digidata1322A, and pClamp9 software (Axon Instruments, Union City, CA, USA). The oocyte was pretreated with an alkaloid for 3 min and then treated with ACh (011-00592, Fujifilm Wako Pure Chemical) for $5 \mathrm{~s}$. Each solution was rapidly switched by using a three-way valve (AG41-02-2-DAC100V Multilex Valve, CKD Corp., Aichi, Japan). To analyze the effects of alkaloids, current response to $\mathrm{ACh}$ in the presence of alkaloid was normalized to control response (i.e., current elicited by $\mathrm{ACh}(100 \mu \mathrm{M}$ for $\alpha 7$ and $1 \mu \mathrm{M}$ for $\alpha 4 \beta 2)$ alone $))$ in each oocyte and then averaged.

\subsection{Ligand-Binding Assays}

The $\left[{ }^{3} \mathrm{H}\right]$ nicotine and $\left[{ }^{3} \mathrm{H}\right]$ methyllycaconitine binding assays using membrane suspensions from whole rat brain (excluding cortex and cerebellum) were performed as described previously [50].

\subsection{In Vitro Effect of the Compound on the Transport of Cationic Compounds at the BBB and Inner $B R B$}

As model cells of the rat BBB and inner BRB, TR-BBB and TR-iBRB2 cells were utilized [48,49]. These cells were cultured following the previous manuscript [51] and seeded onto collagen type I-coated 24-well plate (Corning, Kennebunk, ME, USA) at a density of $5 \times 10^{4}$ cells $/ \mathrm{cm}^{2}$. The cells were cultured for 2 days and then washed with 
extracellular fluid buffer ( $122 \mathrm{mM} \mathrm{NaCl}, 25 \mathrm{mM} \mathrm{NaHCO}, 3 \mathrm{mM} \mathrm{KCl}, 1.4 \mathrm{mM} \mathrm{CaCl}$, $1.2 \mathrm{mM} \mathrm{MgSO} 4,0.4 \mathrm{mM} \mathrm{K} \mathrm{HPO}_{4}, 10 \mathrm{mM}$ D-glucose, $10 \mathrm{mM}$ 2-[4-(2-hydroxyethyl)-1piperazinyl]ethanesulfonic acid- $\mathrm{NaOH}, \mathrm{pH} 7.4)$ at $37^{\circ} \mathrm{C}$. The extracellular fluid buffer containing $\left[{ }^{3} \mathrm{H}\right]$ nicotine $(85 \mathrm{Ci} / \mathrm{mmol}$; American Radiolabeled Chemicals, St. Louis, MO, USA) or [ $\left.{ }^{3} \mathrm{H}\right]$ verapamil $(80 \mathrm{Ci} / \mathrm{mmol}$; American Radiolabeled Chemicals) at a concentration of $0.5 \mu \mathrm{Ci} / \mathrm{mL}$ in the absence or presence of test compounds at $200 \mu \mathrm{M}$ with $1.0 \%$ DMSO was applied to the cells and incubated at $37{ }^{\circ} \mathrm{C}$ for designed time $\left(\left[{ }^{3} \mathrm{H}\right]\right.$ nicotine, 10 sec; $\left[{ }^{3} \mathrm{H}\right]$ verapamil, $\left.3 \mathrm{~min}\right)$. After the uptake reaction, the cells were rinsed with the extracellular fluid buffer at $4{ }^{\circ} \mathrm{C}$ and solubilized in $1 \mathrm{~N} \mathrm{NaOH}$. The solubilized solution was neutralized with $1 \mathrm{~N} \mathrm{HCl}$. The ${ }^{3} \mathrm{H}$-radioactivities derived from the cell-solubilized solution and reaction buffer were measured using an AccuFLEX LSC-7400 liquid scintillation counter (Hitachi, Kashiwa, Japan). Protein concentration in the solubilized solution was quantified by a DC protein assay kit II (BIO-RAD, Hercules, CA, USA). The uptake activities were normalized by the concentration of the radiolabeled compound in the transport buffer and the cellular protein amount in each well. The data were expressed as the percentage of uptake activity in the control group and mean \pm S.E.M. Statistic difference was evaluated using a one-way analysis of variance followed by Dunnett's test.

Supplementary Materials: The NMR spectra $\left({ }^{1} \mathrm{H}-\mathrm{NMR},{ }^{13} \mathrm{C}-\mathrm{NMR}\right)$ of all new compounds are available online.

Author Contributions: T.O., K.T. and J.I. performed the experiments of the synthesis of ent-cis-195A and cis-211A and analyzed synthetic data; H.M., T.I. and T.K. determined the stereochemistry of the intermediate 15; N.W. performed the electrophysiological experiments under supervision by H.T., T.W., T.S. (Toshiyasu Sasaoka), T.S. (Takahiro Shimizu) and H.S. and H.T. partly wrote the corresponding parts; L.P.D. performed the binding assays; Y.Y., S.-i.A., Y.K. and K.-i.H. performed the experiments on nicotine and verapamil transport and partly wrote the corresponding parts; S.R.H. and R.A.S. partly wrote the introduction parts; N.T. conceived the need to synthesize ent-cis-195A and cis-211A and designed the experiment; T.O. and N.T. wrote the paper. All authors have read and agreed to the published version of the manuscript.

Funding: This research received no external funding.

Acknowledgments: We thank Renee Mosi from Edanz (https://jp.edanz.com/ac accessed on 18 November 2021) for editing a draft of this manuscript.

Conflicts of Interest: The authors declare no conflict of interest.

Sample Availability: Samples of cis-195A and cis-211A are available from the authors.

\section{References}

1. Daly, J.W.; Spande, T.F.; Garraffo, H.M. Alkaloids from Amphibian Skin: A Tabulation of Over Eight-Hundred Compounds. J. Nat. Prod. 2005, 68, 1556-1575. [CrossRef]

2. Badio, B.; Daly, J.W. Epibatidine, a potent analgetic and nicotinic agonist. Mol. Pharmacol. 1994, 45, 563-569.

3. Daly, J.W.; Nishizawa, Y.; Padgett, W.L.; Tokuyama, T.; McCloskey, P.J.; Waykole, L.; Schultz, A.G.; Aronstam, R.S. Decahydroquinoline alkaloids: Noncompetitive blockers for nicotinic acetylcholine receptor-channels in pheochromocytoma cells and Torpedo electroplax. Neurochem. Res. 1991, 16, 1207-1212. [CrossRef]

4. Daly, J.W.; Tokuyama, T.; Habermehl, G.; Karle, I.L.; Witkop, B. Frog venoms. Isolation and structure of pumiliotoxin C. Lieb. Ann. Chem. 1969, 729, 198-204. [CrossRef] [PubMed]

5. Ibuka, T.; Inubushi, Y.; Saji, I.; Tanaka, K.; Masaki, N. Total synthesis of dl-pumiliotoxin c hydrochloride and its crystal structure. Tetrahedron Lett. 1975, 16, 323-326. [CrossRef]

6. Oppolzer, W.; Fröstl, W. The total synthesis of (+/-)-pumiliotoxin-C. Helv. Chim. Acta 1975, 58, 593-595. [CrossRef] [PubMed]

7. Habermehl, G.; Andres, H.; Miyahara, K.; Witkop, B.; Daly, J.W. Synthese von Pumiliotoxin C. Lieb. Ann. Chem. 1976, 1577-1583. [CrossRef]

8. Overman, L.E.; Jessup, P.J. Synthetic applications of $\mathrm{N}$-acylamino-1,3-dienes. An efficient stereospecific total synthesis of $d l$-pumiliotoxin C, and a general entry to cis-decahydroquinoline alkaloids. J. Am. Chem. Soc. 1978, 100, 5179-5185. [CrossRef]

9. Hattori, K.; Matsumura, Y.; Miyazaki, T.; Maruoka, K.; Yamamoto, H. Successive Beckmann rearrangement-alkylation sequence by organoaluminum reagents. Simple route to $\mathrm{dl}$-pumiliotoxin C. J. Am. Chem. Soc. 1981, 103, 7368-7370. [CrossRef]

10. LeBel, N.A.; Balasubramanian, N. Stereospecific synthesis of 2,3,6-trisubstituted piperidines: An efficient total synthesis of ( \pm )-pumiliotoxin C. J. Am. Chem. Soc. 1989, 111, 3363-3368. [CrossRef] 
11. Comins, D.L.; Dehghani, A. N-acyldihydropyridones as synthetic intermediates. A short synthesis of $( \pm)$-pumiliotoxin C. Tetrahedron Lett. 1991, 32, 5697-5700. [CrossRef]

12. Brandi, A.; Cordero, F.M.; Goti, A.; Guarna, A. The isoxazoline-5-spirocyclopropane route to ( \pm )-Pumiliotoxin C. Tetrahedron Lett. 1992, 33, 6697-6700. [CrossRef]

13. Polniaszek, R.P.; Dillard, L.D. Stereospecific total syntheses of decahydroquinoline alkaloids ( \pm )-195A and ( \pm )-2-epi-195A. J. Org. Chem. 1992, 57, 4103-4110. [CrossRef]

14. Paulvannan, K.; Stille, J.R. Decahydroquinoline construction through aza-annulation: A stereoselective synthesis of $( \pm)-5-$ epipumiliotoxin C. Tetrahedron Lett. 1993, 34, 6673-6676. [CrossRef]

15. Meyers, A.I.; Milot, G. $\alpha$-Alkylation and stereochemistry of cis- and trans-decahydroquinolines mediated by the formamidine and Boc activating groups. Synthesis of pumiliotoxin C. J. Am. Chem. Soc. 1993, 115, 6652-6660. [CrossRef]

16. Mehta, G.; Praveen, M. Regioselective Haller-Bauer Cleavage in Tricyclo-[5.2.1.0 2,6]dec-8-ene-3,10-dione. A Total Synthesis of ( \pm )-Pumiliotoxin C. J. Org. Chem. 1995, 60, 279-280. [CrossRef]

17. Back, T.G.; Nakajima, K. Use of an acetylenic sulfone as an alkene dipole equivalent in the synthesis of $( \pm)$-pumiliotoxin C. Tetrahedron Lett. 1997, 38, 989-992. [CrossRef]

18. Kuethe, J.T.; Padwa, A. The tandem Pummerer-isomünchnone route to ( \pm )-pumiliotoxin C. Tetrahedron Lett. 1997, 38, 1505-1508. [CrossRef]

19. Padwa, A.; Heidelbaugh, T.M.; Kuethe, J.T. Using the Pummerer cyclization-deprotonation-cycloaddition cascade of imidosulfoxides for alkaloid synthesis. J. Org. Chem. 2000, 65, 2368-2378. [CrossRef]

20. Akashi, M.; Sato, Y.; Mori, M. Synthesis of pumiliotoxine C from molecular nitrogen as a nitrogen Source. J. Org. Chem. 2001, 66, 7873-7874. [CrossRef]

21. Dijk, E.W.; Panella, L.; Pinho, P.; Naasz, R.; Meetsma, A.; Minnaard, A.J.; Feringa, B.L. The asymmetric synthesis of (-)-pumiliotoxin $\mathrm{C}$ using tandem catalysis. Tetrahedron 2004, 60, 9687-9693. [CrossRef]

22. Gärtner, M.; Qu, J.; Helmchen, G. Enantioselective Syntheses of the Alkaloids cis-195A (Pumiliotoxin C) and trans-195A Based on Multiple Applications of Asymmetric Catalysis. J. Org. Chem. 2012, 77, 1186-1190. [CrossRef] [PubMed]

23. Tokuyama, T.; Nishimori, N.; Shimada, S.; Edwards, M.W.; Daly, J.W. New classes of amidine, indolizidine and quinolizidine alkaloids from a poison-frog, Dendrobates pumilio (Dendrobatidae). Tetrahedron 1987, 43, 643-652. [CrossRef]

24. Toyooka, N.; Tanaka, K.; Momose, T.; Daly, J.W.; Garraffo, H.M. Highly stereoselective construction of trans(2,3)-cis(2,6)trisubstituted piperidines: An application to the chiral synthesis of Dendrobates alkaloids. Tetrahedron 1997, 53, 9553-9574. [CrossRef]

25. Toyooka, N.; Okumura, M.; Nemoto, H. Stereodivergent Process for the Synthesis of the Decahydroquinoline Type of Dendrobatid Alkaloids. J. Org. Chem. 2002, 67, 6078-6081. [CrossRef]

26. Toyooka, N.; Fukutome, A.; Nemoto, H.; Daly, J.W.; Spande, T.F.; Garraffo, H.M.; Kaneko, T. Synthesis of alkaloid 223A and a structural revision. Org. Lett. 2002, 4, 1715-1717. [CrossRef]

27. Toyooka, N.; Nemoto, H. First enantioselective synthesis of (+)-quinolizidine 207I: Determination of the absolute stereochemistry. Tetrahedron Lett. 2003, 44, 569-570. [CrossRef]

28. Toyooka, N.; Fukutome, A.; Shinoda, H.; Nemoto, H. Total synthesis of the antipode of alkaloid 205B. Angew. Chem. Int. Ed. 2003, 42, 3808-3810. [CrossRef] [PubMed]

29. Tsuneki, H.; You, Y.; Toyooka, N.; Kagawa, S.; Kobayashi, S.; Sasaoka, T.; Nemoto, H.; Kimura, I.; Dani, J.A. Alkaloids indolizidine $\mathbf{2 3 5} \mathbf{B}^{\prime}$, quinolizidine 1-epi-207I, and the tricyclic 205B are potent and selective noncompetitive inhibitors of nicotinic acetylcholine receptors. Mol. Pharmacol. 2004, 66, 1061-1069. [CrossRef] [PubMed]

30. Toyooka, N.; Nemoto, H.; Kawasaki, M.; Martin Garraffo, H.; Spande, T.F.; Daly, J.W. Enantioselective syntheses of two 5, $9 E$ diastereomers of $\mathbf{2 2 3 V}$, an alkaloid from the poison frog Dendrobates pumilio. Tetrahedron 2005, 61, 1187-1198. [CrossRef]

31. Toyooka, N.; Dejun, Z.; Nemoto, H.; Garraffo, H.M.; Spande, T.F.; Daly, J.W. The enantioselective synthesis of poison-frog alkaloids (-)-203A, (-)-209B, (-)-231C, (-)-233D, and (-)-235B". Tetrahedron Lett. 2006, 47, 577-580. [CrossRef]

32. Toyooka, N.; Dejun, Z.; Nemoto, H.; Garraffo, H.M.; Spande, T.F.; Daly, J.W. Enantioselective syntheses of poison-frog alkaloids: 219F and 221I and an epimer of 193E. Tetrahedron Lett. 2006, 47, 581-582. [CrossRef]

33. Toyooka, N.; Kobayashi, S.; Zhou, D.; Tsuneki, H.; Wada, T.; Sakai, H.; Nemoto, H.; Sasaoka, T.; Garraffo, H.M.; Spande, T.F.; et al. Synthesis of poison-frog alkaloids 233A, 235U, and 251AA and their inhibitory effects on neuronal nicotinic acetylcholine receptors. Bioorg. Med. Chem. Lett. 2007, 17, 5872-5875. [CrossRef] [PubMed]

34. Toyooka, N.; Zhou, D.; Nemoto, H.; Tezuka, Y.; Kadota, S.; Andriamaharavo, N.R.; Garraffo, H.M.; Spande, T.F.; Daly, J.W. Efficient enantio- and diastereodivergent synthesis of poison-frog alkaloids 2510 and trans-223B. J. Org. Chem. 2009, 74, 6784-6791. [CrossRef] [PubMed]

35. Wang, X.; Tsuneki, H.; Urata, N.; Tezuka, Y.; Wada, T.; Sasaoka, T.; Sakai, H.; Saporito, R.A.; Toyooka, N. Synthesis and biological activities of the 3,5-disubstituted indolizidine poison frog alkaloid 239Q and its congeners. Eur. J. Org. Chem. 2012, 7082-7092. [CrossRef]

36. Wang, X.; Li, J.; Saporito, R.A.; Toyooka, N. Enantiodivergent synthesis of the quinolizidine poison frog alkaloid 195C. Tetrahedron 2013, 69, 10311-10315. [CrossRef]

37. Okada, T.; Yamamoto, T.; Kato, D.; Kawasaki, M.; Saporito, R.A.; Toyooka, N. Synthesis of 8-deoxypumiliotoxin 193H and 9-deoxyhomopumiliotoxin 207O. Tetrahedron Lett. 2018, 59, 3797-3800. [CrossRef] 
38. Okada, T.; Ozaki, T.; Yamamoto, T.; Kasahara, H.; Kawasaki, M.; Toyooka, N. Divergent Syntheses of Pumiliotoxin-Type Poison-Frog Alkaloids. ChemistrySelect 2021, 6, 1939-1945. [CrossRef]

39. Demizu, Y.; Shiigi, H.; Mori, H.; Matsumoto, K.; Onomura, O. Convenient synthesis of an enantiomerically pure bicyclic prolineand its $N$-oxyl derivatives. Tetrahedron Asymmetry 2008, 19, 2659-2665. [CrossRef]

40. Comins, D.L.; Dehghani, A. Pyridine-derived triflating reagents: An improved preparation of vinyl triflates from metallo enolates. Tetrahedron Lett. 1992, 42, 6299-6302. [CrossRef]

41. Iwabuchi, Y. Discovery and Exploitation of AZADO: The Highly Active Catalyst for Alcohol Oxidation. Chem. Pharm. Bull. 2013, 61, 1197-1213. [CrossRef]

42. Changeux, J.P. Golden anniversary of the nicotinic receptor. Neuron 2020, 107, 14-16. [CrossRef] [PubMed]

43. Corradi, J.; Bouzat, C. Understanding the bases of function and modulation of $\alpha 7$ nicotinic receptors: Implications for drug discovery. Mol. Pharmacol. 2016, 90, 288-299. [CrossRef] [PubMed]

44. Dineley, K.T.; Pandya, A.A.; Yakel, J.L. Nicotinic ACh receptors as therapeutic targets in CNS disorders. Trends Pharmacol. Sci. 2015, 36, 96-108. [CrossRef] [PubMed]

45. Warnick, J.E.; Jessup, P.J.; Overman, L.E.; Eldefrawi, M.E.; Nimit, Y.; Daly, J.W.; Albuquerque, E.X. Pumiliotoxin-C and synthetic analogues. A new class of nicotinic antagonists. Mol. Pharmacol. 1982, 22, 565-573.

46. Tega, Y.; Akanuma, S.; Kubo, Y.; Terasaki, T.; Hosoya, K. Blood-to-brain influx transport of nicotine at the rat blood-brain barrier: Involvement of a pyrilamine-sensitive organic cation transport process. Neurochem. Int. 2013, 62, 173-181. [CrossRef]

47. Kubo, Y.; Kusagawa, Y.; Tachikawa, M.; Akanuma, S.; Hosoya, K. Involvement of a Novel Organic Cation Transporter in Verapamil Transport Across the Inner Blood-Retinal Barrier. Pharm. Res. 2013, 30, 847-856. [CrossRef]

48. Hosoya, K.; Takashima, T.; Tetsuka, K.; Nagura, T.; Ohtsuki, S.; Takanaga, H.; Ueda, M.; Yanai, N.; Obinata, M.; Terasaki, T. mRNA Expression and Transport Characterization of Conditionally Immortalized Rat Brain Capillary Endothelial Cell Lines; a New in vitro BBB Model for Drug Targeting. J. Drug Target. 2000, 8, 357-370. [CrossRef] [PubMed]

49. Hosoya, K.; Tomi, M.; Ohtsuki, S.; Takanaga, H.; Ueda, M.; Yanai, N.; Obinata, M.; Terasaki, T. Conditionally Immortalized Retinal Capillary Endothelial Cell Lines (TR-iBRB) Expressing Differentiated Endothelial Cell Functions Derived from a Transgenic Rat. Exp. Eye Res. 2001, 72, 163-172. [CrossRef] [PubMed]

50. Dwoskin, L.P.; Wooters, T.E.; Sumithran, S.P.; Siripurapu, K.B.; Joyce, B.M.; Lockman, P.R.; Manda, V.K.; Ayers, J.T.; Zhang, Z.; Deaciuc, A.G.; et al. N,N'-Alkane-diyl-bis-3-picoliniums as nicotinic receptor antagonists: Inhibition of nicotine-evoked dopamine release and hyperactivity. J. Pharmacol. Exp. Ther. 2008, 326, 563-576. [CrossRef]

51. Tachikawa, M.; Okamoto, M.; Hirose, S.; Yoneyama, D.; Akanuma, S.; Terasaki, T.; Hosoya, K. Inner Blood-Retinal Barrier Mediates L-Isomer-Predominant Transport of Serine. J. Pharm. Sci. 2011, 100, 3892-3903. [CrossRef] [PubMed] 